Maria GOŁDA-SOBCZAK

Collegium Europaeum Gnesnense

Uniwersytet im. Adama Mickiewicza, Poznań

\title{
Systemy relacji między państwem a kościołami i związkami wyznaniowymi
}

\section{Kształtowanie się systemu relacji między państwem a kościołami i związkami wyznaniowymi w ujęciu historycznym}

Praktycznie rzecz biorąc, od początków dziejów ludzkości religia odgrywała istotną rolę w życiu społeczeństw, a potem państw. Poczynając od głębokiej starożytności, państwa podejmowały mniej lub bardziej świadomie próby określenia swojego stosunku do religii. Nie można się jednak oprzeć wrażeniu, iż w pierwszym rzędzie liczyła się kwestia odniesień do dominującego wyznania, gdyż w szczególności w starożytności, problem tolerancji, praktycznie aż po czasy pryncypatu, nie był dostrzegany. Religia miała charakter wyznania państwowego i stanowiła spoiwo tożsamości narodowej państwa. Wspólnota polityczna utożsamiana była z religijną, a funkcje państwowe zespolone $\mathrm{z}$ religijnymi. W literaturze wskazuje się, że stopniowo ulegały zatarciu różnice między władzą duchowną a świecką. Podkreśla się, że wyodrębnienie rozmaitych dziedzin religijnych nie prowadziło do ich oddzielenia i uzależnienia ${ }^{1}$. W toku rozwoju historycznego ukształtowały się rozmaite modele stosunków między państwami a istniejącymi na jego obszarze związkami wyznaniowymi. Nie wdając się w szczegóły wypada stwierdzić, że w literaturze podjęto próbę stworzenia typologii stosunku państwa do związków wyznaniowych. Dość powszechnie przyjmuje się przy tym, iż istnieją dwa zasadnicze systemy, a mianowicie system powiązania i system rozdziału kościoła od państwa, w ramach których wyróżnić można rozmaite modele. W systemie powiązania wyróżnia się zwykle monizm religijno-polityczny, cezaropapizm w wersji bizantyjskiej, frankońskiej i germańskiej, papocezaryzm, czyli teokrację papieską i jurysdykcjonalizm w wersji protestanckiej i ka-

1 M. Pietrzak, Prawo wyznaniowe, Warszawa 1993, s. 48 i n.; H. Misztal, P. Stanisz, Prawo wyznaniowe, Lublin 2003, s. 36 i n. 
tolickiej. W systemie rozdziału kościoła od państwa wskazuje się na model francuski oraz model radziecki. Część autorów, obok dwóch wskazanych wyżej systemów (powiązania i rozdziału), wskazuje trzeci system, określając go mianem wzajemnej niezależności państwa od kościoła ${ }^{2}$. Występuje on w dwóch modelach: separacji czystej (amerykańskiej) i separacji skoordynowanej (niemieckiej) ${ }^{3}$.

W ramach systemu powiązania najstarszym modelem był monizm religijno-polityczny występujący w państwach przedchrześcijańskich basenu morza Śródziemnego. Charakteryzował się on jednolitością władzy politycznej i religijnej. Przynależność wyznaniowa miała charakter publiczny. Jak zauważono wyżej, analizując problematykę tolerancji religijnej, w starożytnym Rzymie stopniowo religie tradycyjne ulegały absorpcji przez nowe wierzenia, jednak spoiwem mającym łączyć mieszkańców imperium miał być kult cezarów ${ }^{4}$. Cezaropapizm to kolejny, chronologicznie rzecz ujmując, model relacji między państwem a kościołem w systemie powiązania. Jest to doktryna polityczna głosząca supremację władzy państwowej nad kościelną oraz przyznająca państwu prawa do ingerencji w wewnętrzne sprawy kościoła. Jest to więc system, w którym władza świecka i kościelna skumulowana jest w rękach monarchii. W znaczeniu węższym pojęcie to odnosi się do ustroju panującego w cesarstwie bizantyjskim, gdzie kościół został faktycznie włączony w struktury polityczne państwa i podporządkowany celom państwowym ${ }^{5}$. Obok cezaropapizmu w wersji bizantyjskiej w literaturze wyróżnia się jego odmianę frankońską zainicjowaną po koronacji Karola Wielkiego ${ }^{6}$. Cezaropapizm

2 A. Mezglewski, H. Misztal, P. Stanisz, Prawo wyznaniowe, Warszawa 2006, s. 19.

3 J. Sobczak, Podstawy wiedzy o państwie i prawie, Poznań 2002, s. 116-121; A. Mezglewski, H. Misztal, P. Stanisz, Prawo wyznaniowe, s. 13.

4 M. Jaczynowska, Religie świata rzymskiego, Warszawa 1987, s. 129-131, 138-166 oraz 226-227.

5 M. D. Knowles, D. Obolensky, Historia kościoła, t. 2: 600-1500, Warszawa 1988, s. 68 i n.; J. Haldon, Bizancjum. Zarys dziejów, Warszawa 2006, s. 145-172; M. Angold, Cesarstwo Bizantyjskie 1025-1204. Historia polityczna, Wrocław-Warszawa-Kraków 1993, s 72 i n.; G. Ostrogórski, Dzieje Bizancjum, Warszawa 1968, s. 80 i n.; Świat Bizancjum, t. I: Cesarstwo Wschodniorzymskie 330-641, Kraków 2007, s. 65-69, 97-108, 286 i n.; R. Browning, Cesarstwo Bizantyjskie, Warszawa 1997, s. 53 i n.; W. Haussig, Historia kultury bizantyjskiej, Warszawa 1969.

6 E. M. Hallam, J. Everard, Francja w czasach Kapetyngów 987-1328, Warszawa 2006, s. 36 i n.; Katolicyzm wczesnośredniowieczny, pod red. J. Kellera, Warszawa 1973, s. 10-41; M. Serajski, Idea jedności karolińskiej, Warszawa 1973, passim; A. Gieysztor, Władza Karola Wielkiego w opinii współczesnej, Warszawa 1938, pas- 
w wersji germańskiej miał charakter bardzo szeroki, czemu sprzyjał system feudalny. Za panowania cesarzy z dynastii saskiej stał on się powodem konfliktu cesarstwa z papiestwem o inwestyturę, który zakończył się podpisaniem kompromisowego traktatu wormackiego $(1122)^{7}$. Cezaropapizm pojawia się w czasach późniejszych w okresie reformacji w tezie Lutra o nadrzędności władzy państwowej cuius regio eius religio, był też jednym z elementów absolutyzmu we Francji od czasów Filipa IV Pięknego i absolutyzmu oświeconego w monarchii habsburskiej (józefinizm). Ostatnią próbę realizacji doktryny cezaropapizmu na gruncie europejskim był Kulturkampf ${ }^{8}$.

Występujący w systemie powiązania model papocezaryzmu (teokracji papieskiej), zwany także modelem hierokratycznym, to koncepcja stosunków między państwem a kościołem ukształtowana w średniowieczu, wyrosła pod bezpośrednim wpływem walk i sporów między papieżami a cesarzami niemieckimi. Zasadza się ona na doktrynie nadrzędności papieża, a podstawą jest traktowanie ogółu chrześcijan jako jednej civitas Christiana. Teoria o zwierzchności papieży nad całym światem zachodnim powstała, gdy po wyparciu Longobardów i Bizancjum z Włoch papieże stali się władcami świeckimi w środkowej części półwyspu. W bulli Dictatus Pape z 1075r. ogłoszono, że papież ma nie tylko pełnię władzy kościelnej, ale także w zakresie spraw świeckich wszyscy książęta są mu winni posłuszeństwo łącznie z cesarzem, którego może usunąć z tronu. W bulli Unam Sanctam z 1302 r., wydanej przez Bonifacego VIII w toku sporu z królem Francji Filipem Pięknym, papież podniósł uniwersalną władzę do dogmatu wiary. Przejawem hierokratyzmu było uznanie wyższości prawa kanonicznego nad jakimikolwiek prawami świeckimi oraz możliwość odmowy posłuszeństwa ustawie przez każdego poddanego w razie jej sprzeczności z prawem bożym ${ }^{9}$. Zwolennicy hierokratyzmu

sim; J. Baszkiewicz, Myśl polityczna wieków średnich, Poznań 1998, s. 242 i n.; J. F. Noël, Święte cesarstwo, Warszawa 1998, s. 23 i n.

7 H. J. Berman, Prawo i rewolucja. Ksztaltowanie się zachodniej tradycji prawnej, Warszawa 1995, s. 143.

8 K. Grzybowski, Klasowe podłoże feudalnego papalizmu i absolutyzmu, „Czasopismo Prawno Historyczne" 1953, t. 5, s. 143.

9 Model hierokratyzmu wyrósł z doktryny uniwesraslizmu papieskiego - papilizmu - i rozwinął się najpełniej w XIII w., kiedy za pontyfikatu Innocentego III zakończono dzieło centralizacji Kościoła. Doktryna ta oparta była na ośmiu konstrukcjach teoretycznych: teorii jedności świata, który zbudowany na podobieństwo organizmu człowieka, nie może mieć dwóch głów, tylko jedną - papieską; hierarchii bytów, z któ- 
jako skrajnego nurtu obok doktryny papalistycznej uznawali, że papież sprawuje zwierzchnictwo nad władcami politycznymi w sposób bezpośredni w każdym przypadku, a nie jak głosili inni papaliści, okazjonalnie w następstwie grzechów władców ${ }^{10}$.

Model jurysdykcjonalizmu pojawił się dopiero w wyniku reformacji. Nie wszyscy badacze są zgodni co do potrzeby wyróżnienia tego modelu. Wielu uważa, że jurysdykcjonizm to $\mathrm{w}$ gruncie rzeczy cezaropapizm oparty na innych przesłankach teoretycznych. Sama nazwa jurysdykcjonalizm wywodzi się z włoskiej literatury prawa wyznaniowego. Oznacza ona przewagę jurysdykcji państwowej nad kościelną. Znacząca część polskich badaczy posługuje się terminem model (ewentualnie system) supremacji, zwracając uwagę, że koncepcja ta dominowała w rozwiązaniach ustrojowych państw absolutnych (ale nie tylko w tych państwach) - w zasadzie po rewolucji francuskiej $1789 \mathrm{r}$.

Jurysdykcjonizm protestancki był konsekwencją odrzucenia prymatu papieża przez kościoły protestanckie. Istotą jurysdykcjonalizmu katolickiego było ograniczenie uprawnień papieskich względem kościołów lokalnych. Najostrzejszą formę jurysdykcjonalizmu katolickiego był według niektórych francuski gallikanizm ${ }^{11}$. Za odmianę gallikanizmu

rych bytem najwyższym jest byt najbardziej uduchowiony, czyli papież; teorii wyższych zadań papiestwa i niższych zadań państwa; teorii kościoła jako instytucji doskonałej i państwa jako tworu obarczonego grzechem, głoszącej, iż papież może uchylić grzeszne postanowienia władzy świeckiej, a nawet usuwać władców świeckich; teorii wikariatu głoszącej, że po śmierci cesarza władza powinna wracać do papieża jako „wikariusza chrystusowego”; teorii dwóch mieczy tłumaczącej, że Bóg dał Piotrowi jako biskupowi Rzymu dwa miecze, z których jeden symbolizuje władzę duchowną, drugi świecką, przy czym drugim można władać li tylko na rozkaz kapłanów; teoria papieża jako reprezentanta ludu rzymskiego; teoria darowizny Konstantyna (rzekomy dokument Konstantyna I darowujący papiestwu państwo Rzym, wraz ze wszystkimi prowincjami Italii). Zob. K. Grzybowski, Historia doktryn politycznych i prawnych, Warszawa 1967, s. 133-137.

10 Za autorów spójnej argumentacji na rzecz hierokratyzmu uznaje się kanonistów XII w.: Honoriusza z Autun, Jana Salsbury i św. Bernarda z Clairvaux oraz koncepcje organistyczne Hugona ze św. Wiktora. Zob. J. Baszkiewicz, Państwo suwerenne w feudalnej doktrynie politycznej od poczatku XIV w., Warszawa 1964, s. 63 i n.; B. Szlachta, Hierokratyzm, Warszawa 1999, s. 397-401; J. M. Kell, Historia zachodniej teorii prawa, Kraków 2006, s. 144 i n.

11 Gallikanizm był nurtem politycznym we francuskim Kościele katolickim. Zwolennicy jego począwszy od średniowiecza dążyli do zwiększenia władzy królewskiej nad Kościołem i jego uniezależnienia od papieża. Sama nazwa gallikanizm pojawiała się dopiero w czasie obrad I Soboru Watykańskiego 1869-1870 r. Wczesna koncepcja 
uchodzą józefinizm (febronianizm) ${ }^{12}$, leopoldyzm, tannucizm ${ }^{13}$. Model

gallikanizmu opierała się na pracach legistów, którzy nadawali odpór tezom Bonifacego VIII zawartym w bulli Unam sanctam (1302). Wykład tej doktryny w 83 punktach składa się na dzieło Pierre'a Peithou Les libertés de l'Eglise galiciane (1594), w którym głosił on niezależność synodów, możliwość odwoływania się od decyzji papieskich do soboru, nadzór króla nad instytucjami religijnymi, a Sorbony nad doktryną religijną, król miał być w sprawach doczesnych niezależny od papieża. Władzę papieską na terenie Francji ograniczały, natomiast prawa króla gwarantowały tzw. kanony, czyli ugruntowane zwyczaje i postanowienia synodów. Następne znaczące dzieło to De ecclesiastica et politica protestate Edmunda Richtera, w którym dowodził on wyższości króla nad papieżem w sprawach doczesnych, soboru zaś w sprawach duchowych, a za głowę Kościoła uznawał samego Chrystusa. Władza królewska miała też dokonywać oceny urzędów kościelnych i to także pod kątem zgodności ich działań z prawem kanonicznym. Najwyraźniej dazżenia ruchu sformułował w 1682 r. biskup J. Bossuet w „,czterech gallikańskich artykułach”, zwanych też swobodami gallikańskimi i artykułami organicznymi (Declaratin du clergé gallican sur le pouvoir dans l'Eglise). Głoszono w nich: niezależność królów francuskich od papieża, prymat soboru nad papieżem (zgodnie z ustaleniami soboru w Konstancji), wymóg zgody społeczności kościelnej na rozstrzygnięcia papieża dotyczące spraw wiary, niezmienność dawnych praw kościoła francuskiego i odmawiano papieżowi prawa do detronizacji królów i wzywania poddanych do nieposłuszeństwa monarsze, ponieważ świętemu Piotrowi i jego następcom przyznana została jedynie władza duchowa. Wątki gallikańskiej argumentacji spotykamy także w jansenizmie; zob. A. M. Martimort, Le gallicanisme deBossuet, Paryż 1953, passim; M. Vaussard, Jansenisme et gallicanisme aux origines religieuses de Risorgimento, Paryż 1950, passim.

12 Historycy podkreślają, że gallikanizm rozwinął się zwłaszcza po soborach: w Konstancji (1414 r.), w Bazylei (1431 r.). Głównymi etapami był 1516 r. przyznający królom francuskim prawo obsadzania biskupstw i innych wyższych stanowisk kościelnych oraz uchwalanie przez nadzwyczajne zgromadzenie kleru francuskiego pod naciskiem Ludwika XIV wspomnianych wyżej zasad gallikańskich (Gallikańskich Artykułów Organicznych 1682 r). Artykuły te zostały uchylone w następnym roku przez króla. Gallikanizm ostatecznie upadł po ogłoszeniu dogmatu o nieomylności papieża w sprawach wiary i po przeprowadzeniu we Francji rozdziału kościoła od państwa. Źródłem józefinizmu były idee oświeconego absolutyzmu oraz gallikanizmu. Celem jego było zniesienie przywilejów Kościoła katolickiego w monarchii habsburskiej, a zwłaszcza zapewnienie nad nim kontroli państwa oraz dążenie do przeprowadzenia reformy w wewnętrznym życiu kościoła przez pogłębienie treści religijnych i moralnych, podniesienie dyscypliny kleru, powrót do pierwotnej chrześcijańskiej prostoty i skromności życia. Józefinizm bardzo często sprowadza się w literaturze do zarządzeń administracyjnych likwidujących większość klasztorów oraz przeprowadzających sekularyzację ich majątków (dotyczyło to jezuitów, kamedułów, karmelitów, kapucynów). Podkreśla się, że cesarz Józef II, od którego imienia nurt ten przybrał nazwę, ingerował także w sprawy kultu religijnego. Zniósł liczne dotąd święta katolickie, zakazał kultu niektórych świętych, reglamentował także i to finansowo 
jurysdykcjonizmu we wszystkich jego odmianach odnosił się w gruncie rzeczy do tego wyznania lub tych wyznań, które dominowały w określonym państwie, pozostawiając na uboczu regulacji wyznawców religii mniejszościowych.

Warto zauważyć, że model supremacji państwa nad związkami wyznaniowym przybrał w Rosji carskiej formę mocno zbliżoną do cezaropapizmu. Car uznawany był za głowę Kościoła Prawosławnego, a po likwidacji patriarchy funkcję jego przejęło specjalne kolegium tzw. Święty Synod $^{14}$.

Podkreślić należy, że przedstawione w pracach znawców prawa wyznaniowego koncepcje stosunków między państwem a wyznaniami, w gruncie rzeczy mają rys europocentryczny i nie dostrzegają złożoności związków między państwem a dominującą religią w krajach islamu. W literaturze zwraca się uwagę, że w systemach powiązania państwo ma charakter wyznaniowy, w którym jedna $\mathrm{z}$ religii uzyskuje pozycję uprzywilejowaną. Wyznanie obywateli staje się w ten sposób sprawą publiczną, pozostającą w kręgu zainteresowania organów państwowych. Konsekwencją wyznaniowego charakteru państwa, co znajduje zwykle wyraz w konstytucji, są postanowienia rozmaitych aktów normatywnych, które

ceremonie pogrzebowe oraz śluby. Zapomina się że józefinizm wpisuje się w nurt tolerancji religijnej, gdyż w 1781 r. cesarz Józef II wydał edykt tolerancyjny, który pozostawiając Kościołowi katolickiemu pozycję dominującego wyznania, zapewnił wolność religijną trzem głównym wyznaniom, a mianowicie: luteranizmowi, kalwinizmowi i prawosławiu. Literatura zachodnia „rozpływająca” się nad nowatorstwem józefinizmu nie zauważa, że polska Konstytucja 3 Maja szła znacznie dalej zapewniając wolność wszelkich obrządków i religii. Główne założenia józefinizmu, w szczególności w płaszczyźnie liturgicznej i etycznej opierały się na poglądach katolickiego biskupa niemieckiego J. N. Hotheima (pseud. I. Febronius - dlatego też kierunek ten nosi czasem w literaturze nazwę febronizmu); P. Bernard, The Origins and Josephininzm, Colorado Springs 1964.

13 W księstwie Toskani system nazywano leopoldyzmem - od imienia księcia Leopolda I, zaś na terenie królestwa Neapolu tannucizmem - od imienia ministra w tym królestwie. Z kolei na Sycylii obowiązywała nazwa prawo sycylijskie - od $1098 \mathrm{r}$. działał tam legat papieski mający uprawnienia „legatus natus"; zob. ks. B. Kumor, Historia kościoła, cz. 6: Czasy nowożytne. Kościół w okresie absolutyzmu i oświecenia, Lublin 1985, s. 67 i n.; L. J. Rogier, G. de Berier de Sauvigny, J. Hajjar, Historia kościoła, cz. 4: 1715-1848, Warszawa 1987, s. 64 i n.; Z. Zieliński, Papiestwo i papieże dwóch ostatnich wieków 1775-1978, Warszawa 1983, s. 46-50.

${ }_{14}$ M. Szczaniecki, Powszechna historia państwa i prawa, Warszawa 1997, s. 292; R. Pipes, Rosja carów, Warszawa 2006, s. 247-251; J. Kucharzewski, Od biatego do czerwonego caratu, Gdańsk 1990, s. 46-91. 
zastrzegają piastowanie określonych stanowisk państwowych przez wyznawców religii państwowej, bądź oficjalnej ${ }^{15}$. Najczęściej dotyczy to stanowiska głowy państwa. Przejawem wyznaniowego charakteru państwa jest odmawianie modlitw w parlamentach, umieszczanie symboli religijnych w budynkach i pomieszczeniach urzędów państwowych, w udziale duchownych panującego wyznania w uroczystościach państwowych, w powierzaniu kościołom, bądź związkom wyznaniowym, funkcji publicznych (m.in. prowadzenie cmentarzy, szkół, dokumentów stanu cywilnego). Częstym zjawiskiem jest nauczenie religii jako przedmiotu obowiązkowego we wszystkich szkołach publicznych, czemu towarzyszą czasami specjalne wymogi co do wyznania nauczycieli. Państwa wyznaniowe nakładają na swych obywateli obowiązek publicznego poszanowania Boga, otaczają ochroną prawną religie i organizacje wyznaniowe. Religia panująca lub uprzywilejowana pozostaje pod specjalną ochroną państwa, aczkolwiek nie zawsze przepisy prawa karnego uprzywilejowująją w stosunku do innych wyznań. Niemniej zdarza się, że w niektórych państwach zabrania się, bądź utrudnia, propagowania wśród wyznawców religii panującej innych doktryn religijnych ${ }^{16}$. W państwach, w których

15 K. Orzeszyna, Podstawy relacji między państwem a kościołem w konstytucjach państw członkowskich w Unii Europejskiej. Studium porównawcze, Lublin 2007, s. 62. W literaturze podkreśla się, że państwo wyznaniowe charakteryzuje się afirmacją przez państwo określonej doktryny religijnej oraz formalnym uznaniem w ustawie konstytucyjnej lub umowie konkordatowej jednej religii jako oficjalnie panującej lub jednego kościoła jako kościoła państwowego. W państwach wyznaniowych kościół wyposażony jest przez państwo w szczególne przywileje. Dotyczy to instytucji prawnych oraz płaszczyzny finansowej, a ściśle rzecz biorąc subwencjonowania przez państwo określonych religii. W państwach tego typu kościół państwowy ma uprzywilejowaną, w stosunku do innych kościołów i związków wyznaniowych pozycję. Wynika to z toku wydarzeń historycznych z określonych roli, jakie pełnił on w dziejach państwa. Przyznać należy, że w dobie współczesnej te dziejowe więzy stopniowo się rozluźniają. W literaturze podkreśla się, że współcześnie istniejące demokratyczne państwa mają charakter wyznaniowości otwartej, to znaczy, że nie istnieje zakaz wyznawania innych religii poza oficjalną. W państwach tych gwarantowana jest wolność sumienia i wyznania wszystkim obywatelom, natomiast kościoły nie cieszą się jeszcze równouprawnieniem; zob. A. Bielawska, J. Wiśniewski, K. Żodź, Traktat ustanawiajacy konstytucję dla Europy w porównaniu z konstytucjami państw członkowskich Unii Europejskiej, Poznań 2006, s. 42 i n.

16 Do państw wyznaniowych Unii Europejskiej zalicza się zwykle Republikę Cypru, Królestwo Danii, Republikę Finlandii, Republikę Grecji, Republikę Malty i Zjednoczone Królestwo Wielkiej Brytanii. Konstytucja Cypru w art. 18 gwarantuje wolność religijną jednostek, w tym wolność sumienia i sprawowania kultu. Żaden akt 
prawodawczy, wykonawczy lub administracyjny nie może dyskryminować jakiejkolwiek instytucji religijnej lub religii. Jakkolwiek konstytucyjnie zakazany jest prozelityzm to jednak nie został on zagrożony sankcjami karnymi. Formalnie konstytucja gwarantuje, że na Cyprze nie ma religii dominującej, ani religii państwowej, lecz jednocześnie państwo nie jest świeckie. Autokefaliczna Grecka Cerkiew Prawosławna Cypru uważana jest za osobę moralną prawa prywatnego. Nie jest jednak ani władzą, ani organem. Konstytucja powierza temu Kościołowi niektóre kompetencje, przysługujące zwykle organom państwowym, dotyczące: zawierania małżeństw, udzielania rozwodów, orzekania separacji. Wspomniany Kościół cieszy się autonomią wewnętrzną. A. Emilianides, Państwo i Kościół na Cyprze, w: Państwo i Kościół w krajach Unii Europejskiej, Wrocław 2007, s. 51-64 (tam podstawowa literatura s. 65). Zasada wolności religii, mimo, że nie znalazła się w konstytucji duńskiej z 1849 r. funkcjonowała jednak w praktyce. W obowiązującej obecnie konstytucji z 1953 r. mowa w art. 4 o kościele narodowym, jakim jest Ewangelicki Kościół Narodowy, który z tego tytułu ma być wspierany przez państwo. Nie oznacza to, że inne kościoły i związki wyznaniowe nie mogą uzyskiwać takiego wsparcia. Kościół Narodowy w Danii ma dualistyczna naturę. $Z$ jednej strony jest kościołem państwowym, mającym publiczny obowiązek zapewnienia dostępności usług oraz funkcji religijnych wiary ewangelicko-augsburskiej, z drugiej strony jest demokratyczną instytucją dla większości Duńczyków z reprezentatywnym samorządem lokalnym. Kościół ten podlega parlamentowi oraz ministrowi do spraw kościelnych. Nie posiada autonomii i wszystkie decyzje prawne, które jego dotyczą, muszą być podejmowane przez parlament lub rząd. Zarówno parlament, jak i rząd zobowiązane są do respektowania statusu tego kościoła i jego doktryny. Kościół narodowy w Danii ma status podobny do organów państwowych, a dotyczące go uregulowania są częścią prawa publicznego. Inne związki wyznaniowe to niezależne, autonomiczne instytucje prywatne, zorganizowane w formie prywatnych stowarzyszeń z członkami wnoszącymi na ich rzecz opłaty. Małżeństwo może być zawierane w kościele narodowym, jeśli jedna ze stron jest wiernym tego Kościoła. Wierni należący do innych związków mogą zawrzeć małżeństwo także przed swoimi duchownymi, ale musi on być upoważniony do udzielania ślubów. Zob. I. Dübeck, Państwo i kościól w Danii, w: Państwo i Kościól, s. 81-96 (tam obszerna literatura). Konstytucja Finlandii z 1999 r. gwarantuje wolność sumienia i wyznania jednak status Kościoła Ewangelicko Luterańskiego jest szczególny, co potwierdza treść art. 76 tej konstytucji. Jego funkcjonowanie, organizacja i administracja, określona jest w ustawie o kościele. Jakkolwiek wspomnianemu Kościołowi nie przyznano szczególnego statusu, to jednak pozostaje on zależny od państwa. Zbliżoną do tego Kościoła pozycję ma Kościół prawosławny, w którym z mocy ustawy najwyższym autorytetem jest rząd Finlandii. Nowa ustawa o wolności religijnej z 2003 r. przyznaje szerszą ochronę innym związkom wyznaniowym poza Kościołem Luterańskim i prawosławnym. Autonomia Kościoła Luterańskiego jest tak silna, że tylko on sam może zaproponować zmiany w ustawie o kościele. Tego typu uprawnień nie posiada Kościół prawosławny, mimo że i on rządzi się swoją ustawą. Zarówno Kościół Luterański, jak i prawosławny uprawnione są do otrzymywania środków finansowych od wiernych. Zob. M. Heikkilä, J. Knuutila, M. Scheinin, Państwo i kościót Finlandii, w: Państwo i kościót, 
funkcjonuje system powiązania uznaje się za dni wolne od pracy święta wyznania dominującego, a duchowni takiego wyznania korzystają z rozmaitych przywilejów. W krajach, w których istnieje system powiązania regulacja sytuacji prawnej kościołów lub związków wyznaniowych następuje w drodze jednostronnych aktów normatywnych, wydawanych przez państwo, bądź dwustronnych porozumień zawieranych przez państwo ze związkami wyznaniowymi. Specyficzna sytuacja istnieje w Zjednoczonym Królestwie Wielkiej Brytanii, państwie złożonym z trzech krajów au-

s. 111-123. W Grecji, o której już była mowa kilkakrotnie wyżej, przy okazji omawiania problemu prozelityzmu, dominującą rolę, z mocy Konstytucji art. 3 ust. 1 posiada Kościół Prawosławny złączony doktrynalnie z Ekumenicznym Patriarchatem Konstantynopola. W konstytucji zawarty jest też przepis definiujący święte kanony soborów ekumenicznych zarówno w kwestiach administracyjnych, jak i dogmatycznych. Podkreślić należy, że Prawosławny Kościół w Grecji jest autokefaliczny, czyli samowystarczalny duchowo i niezależny administracyjnie. Godzi się zauważyć, że wspomniany wyżej Kościół Prawosławny w Finlandii jest niezależny tylko administracyjnie. Zob. Ch. Papastathis, Państwo i kościót w Grecji, w: Państwo i kościót, s. 147-163. W myśl Konstytucji Malty z 1964 r. religią tego państwa jest wyznanie rzymskokatolickie, a władze tego Kościoła mają obowiązek i prawo nauczania, które zasady są sprawiedliwe a które złe. Konstytucja zapewnia nauczanie religii rzymskokatolickiej w szkole, gwarantuje obecność krzyża w Parlamencie, szkołach i szpitalach oraz w urzędach publicznych. Każdą sesję Parlamentu rozpoczyna Msza Święta, a każde posiedzenie modlitwa. Zob. U. M. Bonnici, Państwo i kościót na Malcie, w: Państwo i kościót, s. 263-276. W literaturze zauważa się, iż Konstytucja Malty zdaje się łączyć dwa elementy - wolność religii i uprzywilejowaną pozycję Kościoła katolickiego - sytuacja ta ma swoje historyczne korzenie związane z istnieniem i rządami Zakonu Maltańskiego, kiedy prawo kanoniczne było dominującym porządkiem Malty i któremu przyznawano prawo pierwszeństwa nad prawem państwowym. Zob. K. Orzeszyna, Podstawy relacji między państwem a kościołem, s. 90. System między państwem a kościołem obowiązujący na Malcie ewoluuje w kierunku coraz bardziej zrównoważonej pozycji Kościoła katolickiego w stosunku do innych kościołów i wyznań oraz zmierza do poszerzenia gwarancji wolności religijnej. Istotne zmiany nastapiły w tym systemie w początkach $\mathrm{XX}$ wieku, a 1975 roku zniesiono niektóre utrzymujące się jeszcze ciaggle, przywileje Kościoła katolickiego. Relacje państwa z Kościołem katolickim w szczegółowych kwestiach regulowane są na podstawie dziewięciu umów międzynarodowych wiążących Republikę Malty i Stolicę Apostolską. Dotyczą one szkół katolickich, ich finansowania, nauczania religii w szkołach państwowych, spraw majątkowych Kościoła oraz skutków cywilnych małżeństwa kanonicznego i orzeczeń kościelnych. W 1991 roku wszystkie kościoły i wyznania na Malcie uzyskały zakres uprawnień zbliżony, ale jednak ciągle nie tożsamy z tymi, jakie posiada Kościół katolicki. Zob. M. Szafian, Wolność religijna w konstytucjach państw europejskich, w: „Kultura i Prawo”, Materiaty III Międzynarodowej Konferencji na temat „Religia i wolność religijna w Unii Europejskiej” Warszawa 2-4 wrzenia 2002, red. J. Krukowski, O. Theisen, Lublin 2003, s. 54-55. 
tonomicznych, Anglii i Walii, Szkocji oraz Irlandii Północnej, z których każdy ma własny system prawa ${ }^{17}$. Wyznawcy innych religii nie na-

${ }^{17}$ W relacjach kościół państwo sytuacja w Zjednoczonym Królestwie jest wyjątkowo złożona. Istnieje kościół państwowy (tzw. Kościół anglikański, Established Church in England - the Church of England) w Anglii, którego głową (Najwyższym Zwierzchnikiem - Supreme Governor) jest królowa. Jednak kościoły anglikańskie Walii (Church in Wales - utworzone w 1920 r. z walijskich diecezji Church of England) i Irlandii Północnej (Church of Ireland - którego diecezje obejmują całą Irlandię, a nie jedynie Irlandię Północną) zostały oddzielone od państwa i są określane jako - disestablished, a Kościół anglikański w Szkocji (the Episcopal Church of Scotland) jest liczebnie niewielki w porównaniu z Kościołem szkockim (Established Church of Scotland). Królowa jest głową Kościoła episkopalnego, w części południowej królestwa, zaś członkiem Kościoła prezbiteriańskiego reformowanego na północy. Church of England posiada specjalny status na wyspie Isle of Man (gdzie Biskup Sodor i Man zasiada w parlamencie) i na Guernsey oraz Jersey, jednak żadne z tych terytoriów nie jest częścią Zjednoczonego Królestwa. Zjednoczone Królestwo nie mając konstytucji pisanej, nie dysponuje formalną gwarancją konstytucyjną przyznającą wolność religii czy prawo do wolności w samookreślaniu się kościołów. Sytuacja religijna zależy od regionów W Irlandii Północnej i Walii Kościół anglikański cieszy się niezależnością jednak ma charakter „kościoła ustanowionego w Anglii”, natomiast w Szkocji Kościół prezbiteriański jest określany jako „kościół narodowy”. Głowa Kościoła anglikańskiego (król brytyjski) jest określany oficjalnie jako „obrońca wiary”. Tytuł ten został mu przyznany na początku XVI wieku przez papieża Leona X dla obrony wiary katolickiej. Kościoły „ustanowione” Anglii i Szkocji są kościołami narodowymi. Wynika to z Aktu Ustanawiajacego (1700) i Aktu Zjednoczeniowego ze Szkocja (1706); władca składa przysięgę ochrony praw, tak przy wstępowaniu na tron, jak i koronacji (która ma miejsce podczas Mszy Świętej w Kościele Anglii). W praktyce nie może on przeciwstawić się rządowi, który popierany przez większość dwóch parlamentów rezerwuje sobie sprawy „ustanowionych kościołów Anglii i Szkocji”. Organem kompetentnym, aby „ustanawiać prawa” wewnątrz Kościoła Anglii jest Synod Generalny. Zob. B. d'Hellencourt, Les vicissitudes d'une , sécularisation chrétienne" au Royaume-Uni, w: Religions et lad'cité dans 1'Europe des Douze, Paris 1994, s. 127. Jest kompetentny do przyjęcia „norm” we wszystkich sprawach dotyczących Kościoła Anglii-norma ma tę samą rangę co ustawa parlamentarna i może zmieniać lub odwoływać ustawy. Faktycznie władza kościelna jest wykonywana przez hierarchię anglikańską. Jednak ostatecznie to parlament jest kompetentny do wydawania ustaw kościelnych. Synod korzysta z władz, które zasadniczo są zarezerwowane dla działań parlamentu. Jednak parlament zachowuje tu kontrolę: norma przyjęta przez synod może być przedstawiona do zatwierdzenia królewskiego, które jest wymagane do tego, aby mogła uzyskać moc ustawy, tylko wówczas, gdy dwie izby Parlamentu wcześniej ją zatwierdzą. Parlament może normę odrzucić (co zdarza się bardzo rzadko), natomiast nie dysponuje żadną władza, aby zmienić tekst zawierający daną normę. Zob. M. Hill, Church Autonomy in the United Kingdom, w: Church Autonomy. A Comparative Survey, ed. G. Robbers, Frankfurt am Main 2001, s. 271. Kościół An- 
leżących do kościoła państwowego traktowani są jako członkowie zwykłych stowarzyszen ${ }^{18}$. W krajach, w których panującym bądź oficjal-

glii wymaga zgody Parlamentu dla swoich wewnętrznych decyzji, takich jak zmiana modlitewnika $(1927,1928)$ czy udzielanie święceń kobietom. Zob. R. Minerath, Church Autonomy in Europe, s. 381. Prawo kanoniczne Kościoła anglikańskiego zostało przyjęte przez synod bez żadnej interwencji parlamentu. Takie przyjęcie jest możliwe, jednak formalna promulgacja nowej dyspozycji kościelnej wymaga zezwolenia i autoryzacji królewskiej, które są formalnymi aktami wyrażającymi pozycję króla, jako najwyższego rządcy Kościoła anglikańskiego. Każdy inny kościół w Anglii (z wyjątkiem Kościoła szkockiego) przyjmuje dyspozycje, które państwo będzie uznawało jako ,prawo kościelne”. Ponieważ Kościół Anglii stanowi jednak część - w pewnym sensie - państwa, żadna umowa dotycząca relacji między kościołem i państwem nie może być zawarta. Kościół Anglii jest kościołem państwowym, co tłumaczy się w taki sposób, że ustawa kościelna (włączając prawo kanoniczne) jest uważana za integralną część prawa angielskiego. Szkocja ma swój odrębny i różny system prawny w ramach Unii. Stosunki państwo-kościół stanowią kolejny przykład różnicy z Anglią, jako że Kościół Szkocji jest prezbiteriański, nie episkopalny (jeżeli chodzi o formę rządów), a szkockie prawo wykazuje liczne cechy reformacji. Kwestie kościoła i państwa, a także religii i prawa, stanowiły przedmiot dyskusji w Szkocji w dwudziestym wieku. Stosunki te regulowane są ustawą o Kościele Szkocji i deklarowanymi artykułami konstytucji Kościoła Szkocji w sprawach duchowych, które zostały uznane jako prawnie wiążące Kościół. Kościoły Anglii i Szkocji są ustanowionymi oficjalnie kościołami dla religijnych ceremonii państwowych. Są jedynymi organizacjami religijnymi, których autonomia jest ograniczona. Największym wyzwaniem z zakresu autonomii kościoła jest z pewnością sprawa wolności w nauczaniu wiary. Nie jest ona oczywista, ponieważ wyznanie wiary w kościołach ustanowionych przez państwo jest w jakiś sposób zakotwiczone w jego konstytucji. W Wielkiej Brytanii oficjalny kościół nie może dokonać instytucjonalnej integracji z innym kościołem bez zmiany przepisów konstytucyjnych. Paradoksalnie uprzywilejowana pozycja Kościoła Anglii jako Kościoła państwowego ogranicza jego autonomię w wielu przypadkach. Istnieje kontrola parlamentarna dotycząca korzystania przez Synod Generalny ze szczególnych praw przy przygotowywaniu ustaw w materii kościelnej. Nabycie tych praw specjalnych miało miejsce w następstwie przyjęcia Church of England Assembly (Powers) Act z 1919 r., nazywany bardziej powszechnie Enabling Act. Ważność tej ustawy została dokładnie sprawdzona w chwili przyjęcia przez Synod Generalny w 1992 r. ustawodawstwa zezwalającego na święcenia kobiet. Normy konieczne do reformy prawa kościelnego w Anglii zostały przedstawione w Parlamencie stosownie do ustawy z 1919 r. Bardzo kontrowersyjnym ograniczeniem wolności kościoła angielskiego jest prawo Korony - królowej działającej za poradą premiera do mianowania arcybiskupów i biskupów diecezjalnych. Kompetencja ta w wyniku porozumienia zawartego w 1977 r. pomiędzy przywódcami kościoła a ówczesnym rządem ma charakter ograniczony do osób wcześniej nominowanych przez kościół.

${ }_{18}$ Kościół Szkocji otrzymał ochronę na warunkach wynegocjowanych i zawartych w Traktacie o Unii z 1706 roku. Pozostał on dominującym, podczas gdy inne ko- 
nym wyznaniem jest katolicyzm, sytuacja tego kościoła regulowana jest przez konkordat ${ }^{19}$. System powiązania zapewnia także przedstawicielom

ścioły i związki wyznaniowe działały w warunkach licznych niedogodności. Ustawa o Kościele Szkocji zajmuje się przede wszystkim konstytucją tego Kościoła. Jednak w art. 2 stanowi, iż Kościół ten nie może naruszać prawa innego kościoła w Szkocji do uznania go za kościół chrześcijański chroniony przez prawo, gdy chodzi o wykonywanie jego funkcji duchowych, kościoły chrześcijańskie, inne niż Kościół Szkocji, są dobrowolnymi stowarzyszeniami. Jurysdykcja kościołów nad swoimi członkami wynika z prawa ogólnego. Jest to władza podobna do tej, jaką ma klub czy stowarzyszenie w stosunku do swoich członków. Zarząd nad ich majątkiem jest sprawowany przez kuratorów (trustees), jest to warunek wymagany przez sądy. Oznaczać to może, iż przy braku przeciwnych uregulowań, jeżeli istnieje podział w związku wyznaniowym lub zborze, ci, którzy stosują się do „właściwych zasad” kurateli, będą uprawnieni do własności, nawet jeżeli pozostają w mniejszości. Zob. M. Hill, Church Autosomy in the United Kingdom, w: Church Autosomy. A. A Comparative Survey, ed. G. Robbers, Frankfurt am Main 2001, s. 267-283; F. Lyall, Church, Law and the Individual in Scotland, „European Journal for Church and State Research”, t. 9, Leuven 2002, s. 186 i n. Kościół katolicki, podobnie jak wyznania prawosławne i inne wspólnoty, także protestanckie, zrównane są w prawach ze stowarzyszeniami. Ich prawa kanoniczne mają status wewnętrznego statutu takiego stowarzyszenia. Nie istnieje formalna lista kościołów uznanych przez państwo. Pojawiają się także problemy dotyczące tego, czy określona organizacja stanowi kościół. Doświadczył tego kościół scjentologiczny. Według danych brytyjskich poza chrześcijanami w Zjednoczonym Królestwie żyja wyznawcy islamu, hinduizmu, sikhizmu, buddyzmu, judaizmu. Z tym, że chrześcijanie stanowią ponad $71 \%$. Wśród chrześcijan obok wspomnianych już kościołów protestanckich działają mające mniejsze znaczenie kościoły metodystyczne, zielonoświątkowców, prawosławne, babtystów oraz Kościół rzymskokatolicki, w odniesieniu do którego istnieją ciagle pewne ograniczenia prawne. Zob. D. McClean, Państwo i kościót w Zjednoczonym Królestwie, w: Państwo i kościót, s. 407-425.

19 Konkordat jest to szczególna umowa międzynarodowa zawierana między państwem a Kościołem rzymskokatolickim regulująca sytuację prawną tego Kościoła w danym państwie. Ściśle rzecz biorąc, jest to umowa między państwem a Stolicą Apostolską. Jakkolwiek uznanie konkordatu za umowę międzynarodową budziło kiedyś poważne wątpliwości z uwagi na kwestie uznania podmiotowości Stolicy Apostolskiej w prawie międzynarodowym, to jednak obecnie wątpliwości te nie mają już znaczenia. Zob. J. Czaja, Prawnomiędzynarodowy status Watykanu, Warszawa 1983, s. 77-144. Natura prawna konkordatów oraz porozumień prawnych zawieranych przez Stolicę Apostolską z państwami wywoływała w przeszłości liczne dyskusje, w których konfrontowano teorie głoszone przez kanonistów, prawników związanych z kościołem i pozostałych specjalistów prawa międzynarodowego. Teorie kościelne widziały w konkordatach przywilej papieski wydany dla władz określonego państwa, ustalający zakres ich obowiązków w odniesieniu do kościoła lokalnego i jego instytucji (teoria przywileju). Oczywiście konkordat traktowany jako przywilej mógł być każdej chwili cofnięty przez papieża. W opozycji do tych założeń teorię prawników 
religii panującej pomoc władz państwowych. Z drugiej jednak strony umożliwia państwu wywieranie wpływu na obsadę stanowisk kościelnych.

W niektórych ujęciach $\mathrm{w}$ ramach systemu powiązania wyróżnia się chyba niezbyt szczęśliwie model zwierzchnictwa państwa nad związkami wyznaniowymi. Czasami model ten określany jest terminem „,model zwierzchnictwa wyznaniowego", w opozycji do którego funkcjonuje model zwierzchnictwa laickiego istniejący w systemie rozdziału kościoła od państwa $^{20}$. Zwolennicy takiego ujęcia widzą źródła zwierzchnictwa wyznaniowego w Rewolucji Francuskiej z 1789 r. podkreślając, że występujące $\mathrm{w}$ różnych państwach i $\mathrm{w}$ różnym natężeniu procesy laicyzacji państwa i prawa zmniejszały zakres oddziaływania związków wyznaniowych. Istotny wpływ na powstanie tego modelu miała wywrzeć doktryna pozytywizmu prawniczego i wypracowana przez nią koncepcja państwa prawnego $^{21}$. W ścisłym związku ze wspomnianą koncepcją pozostawał

świeckich wychodziły z koncepcji doktryny pozytywistycznej uznającej państwo za jedyne źródło praw obowiązujących na tym terytorium. Teoria ta - nosząca miano teorii legalnej uznawała konkordat za wewnętrzne prawo państwa wydawane w porozumieniu ze Stolicą Apostolską. Zwolennicy tej teorii przyznawali państwom prawo jednostronnego wypowiedzenia konkordatu podnosząc, że nie może ono zawierać układu z własnymi obywatelami, których interesy religijne reprezentuje stolica Apostolska. W Polsce w okresie międzywojennym zwolennikiem teorii legalnej był E. Bursche, Konkordaty. Studium historyczne, Warszawa 1930, s. 2 i n. Wspomniane dwie zwalczające się teorie straciły swą aktualność na rzecz teorii umowy międzynarodowej, która traktuje konkordat jako układ dwustronny, którego stronami są: Stolica Apostolska, jako najwyższy organ władzy w Kościele katolickim oraz konkretne państwo. Jest to efektem potwierdzenia przez Konwencję Wiedeńską z 1980 r. podmiotowości prawno-międzynarodowej Stolicy Apostolskiej. Współcześnie konkordaty, po ich ratyfikacji przez uprawnione organy Stolicy Apostolskiej i państwowe, są wiążące dla państwa i Kościoła katolickiego. Zob. T. Włodarczyk, Konkordaty, Warszawa 1986, s. 9-38 (tam analiza bogatej literatury); J. Wisłocki, Konkordat polski z 1925 roku. Zagadnienia prawnopolityczne, Poznań 1977, s. 19-37; W Górski, Konkordat polski 1993, Warszawa 1998, s. 9-27; J. Krukowski, Konkordat polski, znaczenie i realizacja, Lublin 1999, s. 18-35; tenże, Konkordaty wspótczesne. Doktryna, teksty 1964-1994, Warszawa 1995, s. 44; W. Skrzydło, R. Mojak, Konkordat w świetle prawa konstytucyjnego, w: Nowy konkordat a prawo polskie, red. J. Krukowski, Warszawa 1994, s. 63-94.

${ }^{20}$ Tak widzi tę kwestię M. Pietrzak, Prawo wyznaniowe, s. 55.

${ }^{21}$ W kwestii pojęcia „państwo prawa” zob.: M. Zmierczak, Ksztaltowanie się koncepcji państwa prawnego na przykładzie niemieckiej myśli prawnej, w: Polskie dyskusje o państwie prawa, red. S. Wronkowska, Warszawa 1995, s. 11-27. Znaczna część przywołanego tekstu została opublikowana wcześniej pod tym samym tytułem w: $D e-$ mokratyczne państwo prawne (aksjologia, struktura, funkcje). Studia i szkice, red. 
istotny problem wolności i praw człowieka ${ }^{22}$. W pozytywistycznej kon-

H. Rot, Wrocław 1994, s. 53-68; S. Wronkowska, Zarys koncepcji państwa prawnego w polskiej literaturze politycznej i prawnej, w: Polskie dyskusje o państwie prawa, red. S. Wronkowska, Warszawa 1995, s. 63-80; także, Klauzula państwa prawnego, w: Podstawowe problemy stosowania Konstytucji Rzeczypospolitej Polskiej. Raport wstępny, red. K. Działocha, Warszawa 2004, s. 11-28; W. Sokolewicz, Państwo prawne - jego cechy i kryteria, Wydawnictwo Kancelarii Sejmu. Informacja nr 63 Biura Studiów i Ekspertyz, Warszawa 1992, s. 3 i n.; K. Działocha, Państwo prawne w warunkach zasadniczych zmian systemu prawa RP, „Państwo i Prawo” 1992, z. 1, s. 17; M. Wyrzykowski, Legislacja - demokratyczne państwo prawne - radykalne reformy polityczne i gospodarcze, w: Tworzenie prawa w demokratycznym państwie prawnym, red. H. Suchocka, Warszawa 1997, s. 40 i n.; tenże, Zasada demokratycznego państwa prawnego, w: Zasady podstawowe w polskiej Konstytucji, red. W. Sokolewicz, Warszawa 1998, s. 65-91, szczególnie 66-70; M. Pietrzak, Model demokratycznego państwa prawnego, „Studia Konstytucyjne”, t. VII, s. 14 i n.; tenże, Demokratyczne państwo prawne, „Przegląd Humanistyczny” 1999, nr 6; przedr. tegoż, Demokratyczne świeckie państwo prawne, Warszawa 1999, s. 27-42; P. Tuleja, Zastane pojęcie państwa prawnego, w: Zasada demokratycznego państwa prawnego w Konstytucji RP, red. S. Wronkowska, Warszawa 2006, s. 49-72; J. Zakrzewska, Konstytucyjna zasada państwa prawnego w praktyce Trybunału Konstytucyjnego, „Państwo i Prawo” 1992, z. 7, s. 10; K. Jonca, Ewolucja pojęcia „,państwo prawne” w niemieckiej doktrynie prasowej, „Acta Universitatis Wratislawiensis” nr 307, Przeglad Prawa i Administracji, t. 7, Wrocław 1976; J. Stelmach, Filozoficzne aspekty dyskusji o państwie prawnym, w: Prawo w zmieniajacym się społeczeństwie, red. G. Skąpska, Kraków 1992, s. 221-228. W tekście zanalizowano trzy koncepcje państwa prawnego, a mianowicie: państwa ustaw - Gesetzesstaat, państwa sędziów - Richterstaat, państwa prawnego - Rechtsstaat.

22 Pojęcia ,praw człowieka” i ,państwa prawa” (ewentualnie - ,państwa prawnego”) zrobiły nieprawdopodobną „,karierę” - zarówno w doktrynie, jak i w treści aktów normatywnych z rozmaitych dziedzin prawa. Oba terminy są przy tym używane częstokroć z niezwykłą nonszalancją, a posługujący się nimi politycy, publicyści, a nawet politologowie i prawnicy nie zawsze i nie do końca zdają sobie sprawę z tego, jak kształtowała się koncepcja państwa prawnego, gdzie należy szukać jej źródeł, jakie wywoływała kontrowersje i nieporozumienia. Nie wszyscy chcą także zauważyć genezę praw człowieka i dostrzec ich rozwój. Nie widzą podstaw i powodów, aby zastanawiać się nad pochodzeniem tych praw (problematykę tę poruszył w fascynującym eseju Jan Baszkiewicz, zob. J. Baszkiewicz, Filozoficzne i praktyczne dylematy praw człowieka, w: Meandry tradycji i zakręty ponowoczesności, opr. D. Kurczewski, Rzeszów 2002, s. 49-62). Pomija się problem, czy między państwem prawa a prawami człowieka istnieje swoiste iunctim, czy też pozostają one w całkowitej lub częściowej antynomii. Niektóre z tych kwestii podjął Henryk Olszewski, zob.: H. Olszewski, Odchodzenie od demokracji (Kilka uwag historyka prawa), „Państwo i Prawo” 2006, z. 8 (726), s. 3-15 (referat wygłoszony na posiedzeniu Komitetu Nauk Prawnych Polskiej Akademii Nauk w dniu 1 IV 2006 r., zob. sprawozdanie, ten sam zeszyt, s. 107 i n.). 
Nie sposób w rym miejscu dokonać przeglądu dyskusji nad koncepcjami państwa prawa, zarówno w literaturze światowej, jak i w polskiej, czy podejmować trud dokonania uściśleń terminologicznych, bądź klasyfikacyjnych. W przedmioce genezy państwa prawnego zob.: I. v. Münch, Staatsrecht, t. 1, Stuttgart-Berlin-Köln 1993, s. 135; H. Schanbeck, Von Sinnwandel des Rechtstaates, Schriftenreine der Juristischen Gesselschaft e. V. Berlin, Berlin 1970, s. 1-17. Wypada zauważyć, że kwestie te doczekały się już mniej lub bardziej pogłębionych studiów w literaturze naukowej. Z natury rzeczy wypadało pominąc także kwestie dotyczące genezy, siatki pojęciowej oraz zakresu i charakteru praw człowieka - odsyłając także w tym względzie do ustaleń doktryny. Czyniąc to nie wolno jednak zapominać o tym, że zarówno pojęcie „państwa prawa" (zob. M. Kordela, Państwo praworzqdne i państwo prawne - stosunek pojęć, w: Filozofia prawa i a tworzenie i stosowanie prawa. Materialy ogólnopolskiej konferencji naukowej organizowanej w dniach 11 i 12 czerwca 1991 w Katowicach, red. B. Czech, Katowice 1992, s. 413; także, Zarys typologii uzasadnień aksjologicznych w orzecznictwie Trybunatu Konstytucyjnego, Bydgoszcz-Poznań 2001, passim; J. Wróblewski, Z zagadnień pojęcia ideologii demokratycznego państwa prawnego (analiza teoretyczna), „Państwo i Prawo” 1968, z. 6, s. 9; M. Sobolewski, Koncepcja państwa prawnego (Rechstaat) $w$ doktrynie niemieckiego liberalizmu epoki klasycznej (do 1866), „Państwo i Prawo” 1980, z. 2, s. 130 i n.; R. Radwański, Socjalne państwo prawne w doktrynie RFN 1949-1969, Opole 1985, passim; L. Morawski, Spór o pojecie państwa prawnego, „Państwo i Prawo” 1994, z. 4, s. 17), jak i określenie „praw człowieka" budzą spory i kontrowersje, bywając niejednoznacznie rozumiane, różnie interpretowane, tak samo przez doktrynę, jak i literaturę. Literatura dotycząca praw człowieka jest wyjątkowo obszerna. Wskazać należy jednak na niektóre z opracowań, ograniczając się do tekstów w języku polskim. Wśród nich zobacz: R: Wieruszewski, Prawa człowieka. Model prawny, Wrocław-Warszawa-Kraków 1991, passim; W. Osiatyński, Filozofia i historia praw człowieka, w: Prawa czlowieka a policja. Problemy teorii i praktyki, Legionowo 1994, s. 34 i n.; tenże, W. Osiatyński, Filozofia i historia praw czlowieka, w: Prawa czlowieka a policja. Problemy teorii i praktyki, Legionowo 1994, s. 39; K. Sójka-Zielińska, Drogi i bezdroża prawa, Wrocław-Warszawa-Kraków 2000, s. 88 i n.; B. Banaszak,, Ogólne widomości o prawach człowie$k a$, w: Prawa i wolności obywatelskie w Konstytucji RP, red. B. Banaszak, A. Preisner, Warszawa 2002, s. 17-28; tenże, Prawa jednostki i systemy ich ochrony, Wrocław 1995, s. 48 i n; A. Michalska, Prawa czlowieka w systemach norm międzynarodowych, Warszawa-Poznań 1982, s. 18; także, Podstawowe prawa czlowieka w prawie wewnętrznym a pakty praw człowieka, Warszawa 1976, s. 105; C. Mik, Koncepcja normatywna europejskiego prawa praw człowieka, Toruń 1994, s. 17 i n.; R. Kuźniar, Prawa człowieka. Prawo, Instytucje, stosunki międzynarodowe, Warszawa 2006, szczególnie s. 19-100; Ochrona prawa człowieka w świecie, red. L. Wiśniewski, Bydgoszcz-Warszawa 2000, passim; tenże, Konstytucyjne podstawy ochrony wolności i praw człowieka w Polsce, „Studia Prawnicze” 2003, z. 3 (157), s. 35-62; tenże, Wolności i prawa jednostki oraz ich gwarancje w praktyce, w: Podstawowe problemy stosowania Konstytucji Rzeczypospolitej Polskiej. Raport wstęny, red. K. Działocha, Warszawa 2004, s. 93-152; B. Banaszak, A. Bisztyga, K. Complak, M. Jabłoński, R. Wieruszew- 
cepcji państwa prawnego wszystkie normy prawne musiały wywodzić swoją moc obowiązującą z woli państwa. Organy państwowe miały obowiązek działać w granicach przyznanych im kompetencji. Wszystkie organizacje społeczne na obszarze państwa w tym także kościoły i związki wyznaniowe podlegały władzy organów państwowych w tym sensie, że państwo normowało ich sytuację prawną i określało zakres działania. W modelu tym państwo uznawało jednak walor wartości religijnych. Przejawiało się to w obowiązkowym nauczaniu religii w szkołach publicznych, a także uczestnictwie przedstawicieli związków wyznaniowych w życiu politycznym. Władzę zwierzchnią nad związkami wyznaniowymi wyprowadzono z suwerenności państwowej. Charakterystyczną cechą tego modelu było to, że państwo nie traktowało wszystkich kościołów i związków wyznaniowych w jednakowy sposób. Najczęściej jedno lub dwa wyznania cieszyły się pozycją uprzywilejowaną. Zdarzało się także, że jedno z wyznań miało charakter religii oficjalnej lub państwowej. Wynikało to najczęściej z dziejów państwa, z roli jaką w przeszłości odgrywały w jego historii poszczególne wyznania. Związki wyznaniowe mniejszości religijnych, w szczególności nowo powstające lub nieznane wcześniej na obszarze takiego państwa miały dość zróżnicowany status prawny najczęściej mniej korzystny od tego, jakim cieszyły się kościoły posiadające status religii państwowej lub oficjalnej, często też podlegały nadzorowi ze strony organów państwowych, nieufnie traktujące nowe religie ${ }^{23}$. Sytuację prawną takich związków wyznaniowych regulowały akty normatywne wydawane przez państwo dość często w porozumieniu z kościołami

ski, K. Wójtowicz, System ochrony praw człowieka, Zakamycze 2003, szczeg. s. 13-32; P. Daranowski, Międzynarodowa ochrona praw obywatelskich i politycznych in statu nascendi Międzynarodowy Pakt Praw Obywatelskich $i$ Politycznych, Łódź 1993, s. 14; M. Jabłoński, S. Jarosz-Żukowska, Prawa człowieka i systemy ich ochron. Zarys wykładu, Wrocław 2004, szczególnie s. 16-60, tam dość obszerna bibliografia, s. 314-347; M. Nowak, Trzy generacje praw człowieka, ich znaczenie w świetle przestanek ideowych oraz wświetle ich genezy, w: Prawa człowieka, geneza, koncepcja, ochrona, Wrocław 1993, s. 116-117; P. Tuleja, Normatywna treść praw jednostki w ustawach Konstytucji RP, Warszawa 1997, passim, szczególnie s. 9-28; A. Przyborowska-Klimczak, Europejski system ochrony praw człowieka, „Roczniki Nauk Prawnych" 1991-1992, s. 132; J. Symonides, Polska w europejskich systemach praw człowieka, „Roczniki Polskiej Polityki Zagranicznej”, Warszawa 2002, s. 193.

23 J. Osuchowski, Prawo wyznaniowe Rzeczypospolitej Polski 1918-1939, Warszawa 1967, s. 33 i n.; T. Langer, Państwo a nierzymskokatolickie zwiqzki wyznaniowe w Polsce Ludowej, Poznań 1967, s. 41; M. Pietrzak, Prawo wyznaniowe, s. 56. 
i związkami wyznaniowymi ${ }^{24}$. We wspomnianym modelu nader często konieczność uregulowania sytuacji prawnej Kościoła katolickiego prowadziła do zawierania porozumień ze Stolicą Apostolską. Dało to asumpt do stworzenia teorii koordynacji, u podstaw której leżała forma regulacji sytuacji prawnej kościoła, a nie cechy stosunku między państwem a kościołem. Prowadziło to niektórych do wyodrębnienia osobnego modelu koordynacji jako specyficznej formy powiązania państwa ze związkami wyznaniowymi ${ }^{25}$. Związane jest to $\mathrm{z}$ funkcjonującą teorią układu odnoszącą się do natury konkordatów ${ }^{26}$. Model koordynacji w praktyce uprzywilejowywał nieco te wyznania, które z racji ilości wiernych dominowały w określonych państwach.

24 W literaturze dowodzi się, iż tego typu model wykształcił się najwcześniej w państwach o dominującym wśród ludności wyznaniu protestanckim m.in. w Prusach, Holandii i Szwajcarii. A wśród państw o przewadze ludności katolickiej po pierwszej wojnie w Polsce, na Litwie oraz na Węgrzech. Zob. w tym przedmiocie S. Salmanowicz, Prusy, dzieje państwa i społeczeństwa, Poznań 1987, s. 503; J. Krasuski, Historia Rzeszy Niemieckiej 1871-1945, Poznań 1986, s. 30-37; J. Wąsicki, Zwiqzek Niemiecki i II Rzesza Niemiecka, Poznań 1989, s. 514-525. Odnośnie sytuacji Holandii zob. S. C. van Bijsterveld, Państwo i kościót w Holandii, w: Państwo i kościól, s. 179-196. W odniesieniu do sytuacji na Litwie w okresie międzywojennym zob. G. Błaszczyk, Litwa współczesna, Warszawa-Poznań 1992, s. 82-95; J. Sobczak, Wpływ Władysława Grabskiego na kształt konkordatu między Stolica Apostolskq a Republikq Litewska z 1927 roku, w: Władysław Grabski, uczony i maż stanu, red. J. Konefał, S. Wójcik, Lublin 2005, s. 85-92; tenże Konkordat między Stolica Apostolskq a Republika Litewska z dnia 27 września 1927 r. w opinii prasy polskiej, w: Dzieje Prasy Wielkopolskiej XIX-XX wieku, t. IV, Poznań 1998, s. 165-172; A. Wiskont, Konkordat litewski w zestawieniu z konstytucja państwowa litewska i konkordatem polskim, Wilno 1933, s. 6 i n.; Z. Krajewski, Konkordat z Litwq 1927 roku, „Chrześcijanin w Świecie” 1987, nr 171, s. 70-71; por. J. Kuznecovienè, Państwo i kościót na Litwie, w: Państwo i kościót, s. 215-229.

25 Model ten wyodrębnił H. Świątkowski, Wyznaniowe prawo państwowe. Problematyka prawna wolności sumienia w PRL, Warszawa 1962, s. 9. Wyróżnienie modelu koordynacji stanowi najbardziej kontrowersyjny element systematyki zastosowany przez H. Świątkowskiego. M. Pietrzak, Prawo wyznaniowe, s. 62, traktuje prawo wyznaniowe jako dzieło teoretyków kościelnych wyodrębniających regulowanie sytuacji prawnej Kościoła katolickiego w drodze porozumień ze Stolicą Apostolska, a nie poprzez cechy stosunku między państwem a Kościołem rzymskokatolickim. Większość uczonych pomija model koordynacji przy analizie systemu powiązania.

26 T. Włodarczyk, Konkordaty, s. 18. Warto tu zwrócić uwagę, że ciosem w teorię legalną było zawarcie 31 lipca 1925 r. układu między Litwą a Kościołem ewangelickim unii staropruskiej, którego naczelny organ (Oberkirchenrat) miał siedzibę w Berlinie. Zob. J. Wisłocki, Konkordat polski, s. 22; por także L. Halban, Zanik supremacji państwa nad kościołem w Niemczach, Lwów 1933, s. 54 nadb. z „Pamiętnika Historyczno Prawnego" t. 12, z. 1. 
System rozdziału kościoła od państwa występuje jak już wspomniano, w dwóch modelach francuskim i radzieckim. Pierwszy z nich zapoczątkowany podczas Rewolucji Francuskiej zaowocował dekretem z 21 lutego 1795 r., w którym ustanowiono rozdział państwa od Kościoła $^{27}$. Po Rewolucji Francja jest widownią walk - na szczęście prowadzonych w formie dysput politycznych zwolenników i zaciekłych przeciwników Kościoła katolickiego. Jednym ze źródeł systemu rozdziału była koncepcja szkoły prawa natury w odmianie ateistycznej, drugą ideologia liberalna oraz myśl socjalistyczna ${ }^{28}$. Po roku 1879 antyklerykalizm znalazł się wśród politycznego programu republikanów. W latach 80-tych XIX stulecia uchwalono szereg antyklerykalnych ustaw godzących w Kościół katolicki. Doprowadziło to w 1904 r. do zerwania stosunków dyplomatycznych ze Stolicą Apostolską ${ }^{29}$. Proces rozdzielania kościoła od państwa został zakończony ustawą z 9 grudnia 1905 r. Wprowadziła ona na nowo proklamowaną podczas Rewolucji zasadę wolności sumienia

27 Antyklerykalizm francuski narodził się najprawdopodobniej około połowy XVI w. w tych środowiskach libertyńskich, które występowały z mniej lub bardziej otwartą krytyką obyczajów panujących w Kościele katolickimi miały swoich czołowych przedstawicieli w osobach Etienne'a Doleta (1509-1546), Etienne'a Pasquiera (1528-1615) oraz Michaela Montaigne'a (1533-1592). Zob. A. Nowicki, Filozofia francuskiego odrodzenia, Warszawa 1973, passim. W wieku XVII grono to poszerzyło się o dość liczną grupę ludzi sztuki i nauki poddających w wątpliwość nie tylko obyczaje kościoła, ale także wierzenia. Zob. J. S. Spink, Libertynizm francuski od Gassendiego do Voltaire, Warszawa 1974, passim. Najżywszy atak na Kościół katolicki oskarżany o szerzenie ciemnoty, fanatyzmu, tyrani, nędzy, wiarołomstwa i obłudy został przypuszczony w XVIII w. Do szczególnie zajadłych krytyków należeli Meslier i Voltaire. Zob. P. Hazard, Myśl europejska XVIII wieku. Od Monteskiusza do Lessinga, Warszawa 1972, s. 34 i n.; P. Chaunu, Cywilizacji wieku oświecenia, Warszawa 1989, s. 225-255; M. Skrzypek, Naturystyczna teoria religii we francuskim oświeceniu, „Studia Religioznawcze” 1970, nr 3, s. 21-68; tenże, Euhemeryzm francuskiego Oświecenia. Encyklopedyści $i$ apologeci chrześcijaństwa, „Euhemer” 1969, nr 3, s. 93-106; tenże, Teoria religii u Holbacha, „Euhemer” 1973, nr 4, s. 67-80; tenże, Meslier i Marks, „Euhmer” 1977, nr 1, s. 85-96.

28 Z. Drozdowicz, Liberalizm wyzwaniem ideowym, w: Liberalne wyzwania, Poznań 1998, s. 31-47; M. Novak, Liberalizm - sprzymierzeniec czy wróg Kościoła, Poznań 1993, s. 150 i n.; M. Skrzypek, Oświecenie francuskie a poczatki religioznawstwa, Wrocław-Warszawa-Kraków-Gdańsk-Lódź 1989, s. 326-356 i 367-393; A. Nowicki, Ateizm francuskich materialistów XVII wieku, „Myśl Filozoficzna” 1955, nr 5-6, s. 288-307.

29 Nieprzejednane stanowisko Watykanu wobec koncepcji liberalnych pogłębiało jedynie przepaść między państwem a kościołem; zob. D. Fahey, Naturalizm masońsko-żydowski, Warszawa 1997, s 23 i n.; M. Novak, Liberalizm-sprzymierzeniec czy wróg Kościoła, s. 150. 
i wyznania, traktując religię jako problem prywatny. Pozbawiała też kościół osobowości prawnej. Zagwarantowano wolność publicznego kultu likwidując status „kościołów uznanych”. Wszelkie kościoły i związki wyznaniowe przestały być instytucjami publicznymi, stając się częścią sektora prywatnego. Model rozdziału kościoła od państwa wprowadzony we Francji ustawą z 1905 r. uważany jest za klasyczny model europejski ${ }^{30}$. W modelu francuskim państwo traktuje religię jako sprawę prywatną poszczególnych osób, określając ustawami granicę wolności kościołów i związków wyznaniowych. Czuwa także nad rozdzieleniem państwa, kościołów i związków wyznaniowych, przy czym traktuje te ostatnie jako organizacje prywatne, którym państwo może udzielić pomocy, ale z którymi nie współpracuje ${ }^{31}$. Świecki charakter państwa we Francji determinuje wolność religijną i równość przekonań. Ustawa z 1905 r. przyjmowana była jako synonim świeckości agresywnej, dążenie do wyeliminowania wpływów religijnych, w szczególności Kościoła katolickiego z obszarów spraw publicznych. W chwili obecnej świeckość państwa jest podstawą zasad prawnych mających na celu zapewnienie neutralności władz państwowych w sprawach religijnych oraz zabezpieczenia równego traktowania różnych przejawów życia religijnego. W literaturze podkreśla się, że zasada świeckości państwa proklamowana w art. 1 obecnie obowiązującej Konstytucji francuskiej, podkreślając neutralność państwa nakłada na nie obowiązek nieprzyjmowania żadnej pozycji w płaszczyźnie religijnej ${ }^{32}$. Oznacza to, iż państwo nie może również przyjmować pozycji antyreligijnej czy nieżyczliwej względem religii i to nie tylko co do wyznania, ale

${ }^{30}$ B. Basdevant-Gaudemet, Państwo i kościót we Francji, w: Państwo i kościót, s. $123-145$.

31 A. Czochara, Stosunki państwo - kościót. Belgia, Francja, Hiszpania, Włochy, Warszawa 1994, s. 33-34 i 71; tenże, Mechanizmy ochrony wolności sumienia $i$ wyznania w państwach Europy Zachodniej, w: Dylematy wolności sumienia $i$ wyznania w państwach wspótczesnych, red. A. Czochara, B. Górowska, M. Nadolski, J. Osuchowski, Warszawa 1994, s. 34; K. Orzeszyna, Systemy relacji między państwem i kościołem we Francji, „Roczniki Nauk Prawnych”, 12 (2002), z. 1, s. 248; tenże, Wspótczesne interpretacje francuskie koncepcji państwa świeckiego, „Roczniki Nauk Prawnych" 13(2003), z. 1, s. 222.

${ }^{32}$ Konstytucja Republiki Francuskiej z 4 października 1958 r., wedlug stanu prawnego na dzień 22 lutego $1996 r$., wstęp i thumaczenie W. Skrzydło, Warszawa 2000, s. 33 (tytuł na okładce Konstytucja Francji); zob. także: W. Skrzydło, Ustrój polityczny Francji, Warszawa 1992, s. 51; E. Gulewicz, System konstytucyjny Francji, Warszawa 2000, s. 20-21; B. Margueritte, Francuski model stosunków państwo - kościót, w: Religia - tożsamość - Europa, red. P. Mazurkiewicz, S. Sowiński, Wrocław-Warszawa-Kraków 2005, s. 177-184. 
także co do etyki i nauczania. Koncepcja ta zakłada, że państwo przestaje być świeckie, jeśli faworyzuje systematycznie sekularyzację społeczeństwa, gdyż wówczas traci neutralność. Świeckość dotyczy jedynie państwa, a nie społeczeństwa, które jako całość a także jego poszczególni członkowie mają prawo do wolności religijnej ${ }^{33}$. Jako główne cechy tego modelu wskazywano ponadto: równouprawnienie wyznań działających w oparciu o prawo o stowarzyszeniach, likwidację wszelkiego rodzaju przywilejów wyznaniowych, sekularyzację organów państwowych i rezygnację z usług związków wyznaniowych, świadczonych na rzecz państwa (odebranie związkom wyznaniowym prawa prowadzenia akt stanu cywilnego, likwidacja instytucji kapelanów wojskowych, więziennych, szpitalnych itp.). W ramach tego systemu niekiedy występowało: przejęcie dóbr kościelnych przez państwo, pozbawienie związków wyznaniowych osobowości prawnej, likwidacja nauki religii, pozbawienie praw wyborczych „pracowników kultu”34. W literaturze podkreśla się, iż model francuski, określany także mianem separacji wrogiej, wystąpił w niektórych państwach europejskich, a mianowicie w Belgii, we Włoszech a poza Europa w Brazylii i Meksyku chociaż w tym ostatnim państwie kopiowano obok wzorów francuskich rozwiązania przyjęte w Stanach Zjednoczonych Ameryki Północnej ${ }^{35}$. W niektórych ujęciach do państw świeckich z rady-

33 J. Krukowski, Kościót i Państwo. Podstawy relacji prawnych, Lublin 2000, s. 50; tenże, Państwo światopogladowo neutralne?, w: Problemy wspótczesnego kościoła, red. M. Rusecki, Lublin 1997, s. 30-31; K. Orzeszyna, Podstawy relacji, s. 99-107.

${ }^{34}$ W. Wysoczański, Prawo wewnętrzne kościołów $i$ wyznań nierzymskokatolickich w PRL, Warszawa 1971, s. 23; H. Świątkowski, Wyznaniowe prawo państwowe, s. $10 \mathrm{in}$.

35 J. Krukowski, Kościót i państwo, s. 52-53. Warto zauważyć, że prezentowane ujęcie nie jest jedyne w literaturze i przedstawiając relację między państwem a kościołami częstokroć wymienia się systemy państw wyznaniowych, świeckich z radykalnym rozdziałem między państwem a kościołem, świeckich z rozdziałem przyjaznym z wyraźnym uznaniem pozycji prawnej niektórych kościołów z przyczyn historycznych oraz z rozdziałem przyjaznym bez wyraźnego uznania prawnej pozycji jednego z kościołów. Tak widzi wspomniany problem K. Orzeszyna, Podstawy regulacji, s. 356-358 oraz 41 i n. Pamiętać należy, iż stosunek państwa do kościołów i związków wyznaniowych ulegał w różnych państwach ewolucji w rozmaitych zresztą kierunkach. Generalnie można zauważyć tendencję polegającą na odchodzeniu od koncepcji państwa świeckiego, przy czym świeckości państwa nie można utożsamiać z sekularyzmem, czyli eliminacją wartości religijnych a zawłaszcza wartości chrześcijańskich z życia publicznego. W kwestii sekularyzacji zob. J. Mariański, Sekularyzacja i desekularyzacja w nowoczesnym świecie, Lublin 2006, passim; zob. także M. Tomka, Główne tendencje przemian religijnych w Europie a szczególnie w Europie Środkowowschodniej, w: Metodologiczne problemy badań nad religijnościa, red. J. Mariański, S. H. Zaręba, Ząbki 2002, s. 9-16. 
kalnym rozdziałem między państwem a kościołem, obok Francji zalicza się Holandię ${ }^{36}$ i chyba niezbyt słusznie Irlandię ${ }^{37}$.

36 W Holandii podstawa relacji między państwem a kościołami i związkami wyznaniowymi nie została określona w Konstytucji. Jednak zasadę rozdziału wyprowadza się $\mathrm{z}$ gwarancji wolności religijnej $\mathrm{w}$ wymiarze indywidualnym, interpretując ją w harmonii z zasadą neutralności państwa oraz wolności religii czy wierzeń. Zasada ta wydaje się jednak niedookreślona. W art. 6 Konstytucji zagwarantowano zarówno wolność wierzeń religijnych, jak i niereligijnych. W doktrynie holenderskiej przyjmuje się, że konstytucyjnej ochronie podlega nie tylko wolność do posiadania przekonań religijnych czy niereligijnych, ale również działania stosowne do tych przekonan. Ustawodawca chroni wyrażanie wiary nie tylko przez jednostki, ale także przez grupy religijne i organizacje wyznaniowe. Zawiera się to w klauzuli „każdy ma prawo, indywidualnie, jak też wspólnie z innymi do swobodnego wyznawania swoich przekonań religijnych czy światopoglądowych, ale każdy ponosi za to odpowiedzialność przewidzianą w ustawie". Zob. Konstytucja Królestwa Holandii, thumaczenie i wstęp A. Głowacki, Warszawa 2003, s. 34 (tytuł na okładce Konstytucja Holandii). Por także M. Korzeniowski, Spoleczne uwarunkowania holenderskiej kultury prawnej, „Studia Socjologiczne" 2001, nr 1, s. 55-80. W kwestii systemu politycznego Holandii A. Głowacki, System konstytucyjny Holandii, Warszawa 2003, zwłaszcza s. 11-13 i 45.

${ }^{37}$ Irlandia w świadomości Polaków traktowana jest jako państwo wyznaniowe. Tymczasem w 1871 r. kiedy kościół Irlandii utracił swój państwowy charakter, prawo irlandzkie zaakceptowało zasadę rozdziału kościoła od państwa, za wyjątkiem systemu oświaty. Do 1871 r. anglikański kościół Irlandii był kościołem państwowym mimo, iż znacząca część ludności Irlandii to katolicy. Konstytucja 1922 r. gwarantowała wolność sumienia i wyznania oraz praktykowania religii. Natomiast w art. 44 Konstytucji w wersji z 1937 r. państwo uznawało „szczególną pozycję Świętej Stolicy Apostolskiej i Kościoła rzymskiego, jako strażnika Wiary wyznawanej przez większość obywateli”. Jednocześnie w tym, przepisie uznawano również „Kościół Irlandii, Prezbiteriański Kościół Irlandii, Metodystyczny Kościół Irlandii, Religijne Stowarzyszenie Przyjaciół Irlandii, jak również Kongregację Żydowską i inne wyznania istniejące w Irlandii w chwili uchwalania tej konstytucji”. W referendum przeprowadzonym w 1972 r. wyborcy opowiedzieli się za nowelizacją konstytucji i uchyleniem wspomnianych wyżej przepisów. Stosunki między państwem a Kościołem rzymskokatolickim nie są regulowane konkordatem, a państwo nie odgrywa formalnej roli przy obsadzie wyższych stanowisk kościelnych. Jakkolwiek według współczesnego prawa irlandzkiego wszystkie kościoły i zgromadzenia mają taką samą pozycję, to jednak nie uzyskują one automatycznie osobowości prawnej. W literaturze stwierdza się, że Irlandia utrzymuje system rozdziału między państwem a kościołem, ale jest to system sprzeciwiający się każdej formie laicyzmu. W Konstytucji Irlandii stwierdzono wszakże, iż „Państwo uznaje, że hołd kultu publicznego jest należny Bogu Wszechmogącemu ono powinno czcić jego imię i szanować i czcić religię". Zob. Konstytucja Irlandii, Warszawa 2006, s. 13. Tekst Konstytucji zdaje się jednak naruszać wolność ateistów i agnostyków. O relacji między państwem a kościołem Irlandii zob. J. Casey, Państwo i kościót Irlandii, w: Państwo i kościót, s. 197-213; także K. Orzeszyna, Podstawy relacji, s. 113-118. 


\section{Warto zauważyć, że Belgia ${ }^{38}$ i Włochy ${ }^{39}$ bywają zaliczane do państw świeckich z przyjaznym rozdziałem między państwem a kościołem i wy-}

38 J. Krukowski zaliczył Belgię do państw hołdujących francuskiemu modelowi świeckiemu tylko dlatego, że w Konstytucji uchwalonej 7 lutego 1831 r. zagwarantowano wolność wyznania i sumienia jako prawo należne wszystkim obywatelom, a religię katolicką potraktowano na równi z innymi wyznaniami. Obecnie obowiązujący tekst Konstytucji jest historycznym kompromisem między katolikami i liberałami, przy czym liberałowie porzucili swoje zamiary wykonywania całkowitego nadzoru nad kościołem, a politycy katoliccy przestali domagać się uprzywilejowanej pozycji dla Kościoła rzymskokatolickiego. W literaturze belgijskiej wręcz kwestionuje się rozdział kościoła od państwa. Niektórzy interpretują odpowiednie przepisy jako „wzajemną niezależność” kościoła i państwa. Zob. P. Errera, Traité de droit public belge, Giard et Brie, Paris 1918, s. 87; F. Laurent, L'Èglise et l'Ètat en Belgique, Brussels-Leipzig 1962, s. 351.

39 Włochy są zasadniczo krajem katolickim. Zjednoczenie Włoch (1860-1870) spowodowało poważny kryzys w stosunkach pomiędzy Kościołem katolickim a nowopowstałym państwem. Liberalny rząd Cavoura i jego następcy rozpoczęli proces sekularyzacji instytucji i życia publicznego, np. poprzez wprowadzenie obowiązkowego małżeństwa cywilnego w 1865 r., ograniczenie katechezy w szkołach państwowych w 1877 r., reformę prawa karnego w zakresie ochrony religii w 1889 r., państwową kontrolę nad instytucjami opieki społecznej i dobroczynnymi w $1890 \mathrm{r}$. Zmianom tym sprzeciwiała się hierarchia kościelna, co później poskutkowało wprowadzeniem środków zmierzających do zmniejszenia ekonomicznej władzy Kościoła, w szczególności przez likwidację pewnych jednostek kościelnych i konfiskatę ich mienia, co nastąpiło w latach 1866-1867. Fakt, że zjednoczenie Włoch zostało osiagnięte poprzez zniszczenie świeckiej władzy papieży oraz zdobycie Rzymu we wrześniu 1870 r., spowodował szczególnie silną wrogość wielu katolików wobec królestwa Włoch. Umiarkowana polityka rządu po opublikowaniu ustawy o gwarancjach stopniowo zredukowała te napięcia. Wybuch I wojny światowej uniemożliwił jednak zbliżenie między państwem a kościołem. Próbę pojednania z Kościołem podjęła partia faszystowska. Kulminacją tych dążeń było podpisanie Traktatów Laterańskich (zwane także w literaturze Konkordatem Laterańskim) z 1929 r., które przywróciły niektóre z przywilejów kościelnych. Traktaty Laterańskie to ściśle rzecz biorąc trzy dokumenty: Traktat regulujący stosunki między Włochami a Stolicą Apostolską notyfikujący powstanie Państwa Watykańskiego - Cità del Vaticano, Układ Finansowy i Konkordat. Podstawy statusu Kościoła katolickiego we Włoszech określono w konkordacie, który został zawarty w dniu 11 lutego 1929 r. Zgodnie z postanowieniami tej umowy zagwarantowano Kościołowi szeroki zakres wolności działania. Zapewniono nienaruszalność budynków służących celom kultowym. Uregulowano kwestię osobowości prawnej kościelnych jednostek organizacyjnych oraz zapewniono ich prawo do posiadania i dysponowania majątkiem. Uznano skutki cywilne małżeństw zawieranych w formie kanonicznej oraz określono warunki cywilnej skuteczności kościelnych orzeczeń dotyczących nieważności małżeństwa. Zagwarantowano nauczanie religii w szkołach publicznych, uznając nauczanie doktryny chrześcijańskiej za ukoronowanie procesu kształcenia i wychowywania. Szczególną ochronę prawną zapewniono 
raźnym uznaniem pozycji prawnej określonych kościołów z racji historycznych. W modelu tym kościoły i związki wyznaniowe traktowane są jednakowo, aczkolwiek przyznać należy, iż zrodził się on w opozycji do Kościoła rzymskokatolickiego.

Model radziecki ukształtował się w ZSRR bezpośrednio po Rewolucji, a jego podstawowe założenia starano się przeszczepić w różnym zresztą zakresie i z różnym skutkiem w państwach socjalistycznych należących do tzw. obozu socjalistycznego. Punktem wyjścia dla tego mode-

również osobom duchownym oraz zakonnikom. Zawarcie konkordatu przyniosło więc kres restrykcyjnej polityki prowadzonej wobec Kościoła katolickiego w pierwszych dziesięcioleciach po zjednoczeniu Włoch. W zamian za gwarancje udzielone Kościołowi ówczesny reżim zamierzał uzyskać polityczną lojalność hierarchii katolickiej. Biskupi zostali zobowiązani do złożenia przysięgi wierności wobec państwa włoskiego oraz ustanowionego zgodnie z prawem króla i rządu. Władzom państwowym zapewniony został również wpływ na obsadę stanowisk kościelnych. Osobom duchownym oraz zakonnikom wyraźnie zabroniono przynależności do partii politycznych oraz angażowania się w akcje o charakterze politycznym. Wolność działania Akcji Katolickiej oraz związanych z nią organizacji ograniczono do rozpowszechniania i realizacji zasad katolickich, z wyłączeniem jakiejkolwiek działalności politycznej. Na mocy art. 7 Konstytucji, zostało zawarte pomiędzy państwem a Kościołem katolickim w dniu 18 lutego 1984 r. Porozumienie z Villa Madama (Accordo di Yilla Madama), zastępujące Traktaty Laterańskie z 1929 r. W ślad za nim zawarto szereg szczegółowych porozumień, z których najważniejsze dotyczyło uregulowania jednostek kościelnych i własności (1984), nauki religii katolickiej w szkołach państwowych (1985), świąt kościelnych (1985), ochrony dziedzictwa kościelnego i kulturowego (1996), opieki duszpasterskiej w siłach policyjnych (1999). Zgodnie z art. 8 ust. 3 zostały zawarte porozumienia (intese) pomiędzy państwem włoskim a Tayola Valdese (waldensi, 1984), Chrześcijańskimi Kościołami Adwentystów Dnia Siódmego (1986), Assemblee di Dio („Zgromadzenia Boga”, Kościół Zielonoświątkowy) (1986), Unią Gmin Wyznaniowych Żydowskich (1987), Chrześcijańską Unią Ewangelicko-Baptystyczną (1993) oraz Kościołem Luterańskim (1993). Dwa kolejne porozumienia z Chrześcijańską Kongregacją Świadków Jehowy i Unią Buddyjską zostały podpisane w 2000 r., ale nie zostały jeszcze ratyfikowane przez Parlament. Sytuacja prawna pozostałych wyznań jest $\mathrm{w}$ dalszym ciągu uregulowana ustawą nr 1159 z 24 czerwca $1929 \mathrm{r}$. Ustawa ta, ze względów historycznych, związanych z jej wprowadzeniem, zawiera kilka norm, które zdają się być niezgodne z konstytucją; jakkolwiek propozycja ich reformy, zatwierdzona przez radę ministrów w 1990 r., do tej pory nie została przedstawiona parlamentowi do zatwierdzenia. Zob. P. Stanisz, Porozumienia w sprawie regulacji stosunków między państwem i niekatolickimi zwiqzkami wyznaniowymi we włoskim porzqdku prawnym, Lublin 2007, s. 23-148 (tam zestawienie obszernej literatury dotyczącej tych kwestii). W języku polskim umowy między Stolicą Apostolską a Włochami niezwykle szczegółowo zanalizował T. Włodarczyk, Konkordaty, t. 2, s. 175-219; por. także M. Nowaczyk, Z. Stachowski, Konkordat z Włochami, Warszawa 1989, passim. 
lu był dekret komisarzy ludowych z 23 stycznia 1918 r. o oddzieleniu kościoła od państwa i szkoły od kościoła. Przepisy tego dekretu zrywały związki między Kościołem prawosławnym a państwem, pozbawiając ten Kościół całkowicie wpływu na nauczanie. Likwidowały także wszelkie przywileje nadane wcześniej Kościołowi prawosławnemu ${ }^{40}$. Kościół prawosławny, inne kościoły i związki wyznaniowe, a także wszelkie wspólnoty kościelne i religijne zgodnie z art. 10 tego dekretu uznane zostały za stowarzyszenia i pozbawiono je jakichkolwiek przywilejów oraz opieki ze strony państwa oraz instytucji lokalnych i autonomicznych. Jako stowarzyszenia zostały pozbawione osobowości prawnej, możliwości posiadania własności. Wszystkie dobra kościelne wszelkich wyznań nie tylko Kościoła prawosławnego zostały znacjonalizowane. W późniejszych aktach normatywnych zastapiono nazwę ,stowarzyszenie kościelne” terminem „grupa wierzących”. Zasady te potwierdziła konstytucja RRFSR z 10 lipca 1918 r., a następnie konstytucja RRFSR z 24 maja 1925 r. wreszcie konstytucja ZSRR z 5 listopada 1936 r. $^{41}$ (zauważyć należy, że w niektórych opracowaniach konstytucja ta nosi datę 5 grudnia - jest to wynikiem stosowania w Rosji kalendarza juliańskiego), która werbalnie zagwarantowała wolność sumienia i wyznania wszystkich obywateli oraz ich równość wobec prawa bez względu na rasę, narodowość, płeć lub wyznanie. Istotne znaczenie miało też wydanie 8 kwietnia 1929 r. przez Ogólnorosyjski Centralny Komitet Wykonawczy i Radę Komisarzy Ludowych aktu prawnego o związkach wyznaniowych. Normował on całokształt spraw związanych z rejestracją związku wyznaniowego, działalnością wyznaniową oraz użytkowaniem „domów kultu” i przedmiotów związanych z kultem. W treści tego aktu normatywnego podkreślono, że związki wyznaniowe nie mogą się mieszać do spraw polityczno-społecznych ${ }^{42}$. Wspomniane akty normatywne starały się wcielić w życie założenia ideologii marksistowsko-leninowskiej zakładającej upadek wszelkich religii i zastapienie ich światopoglądem ateistycznym ${ }^{43}$. Od samego początku

40 J. Myszor, Sowiecki model rozdziału państwa od kościoła, „Chrześcijanin w Świecie" 1994, 196, nr 4, s. 43-53.

41 W art. 124 tej Konstytucji wyrażono zasadę wolności sumienia i wyznania, oddzielenie kościoła od państwa, wolność wykonywania kultu i prowadzenia propagandy antyreligijnej, por. Sowietskije konstitucii, Moskwa 1963, s. 265-268.

42 Został on zmieniony na mocy dekretu Prezydium Rady Najwyższej ZSRR z 19 października 1962 r.

43 Punktem wyjścia było stwierdzenie W. I. Lenina ,Religia - to opium dla ludu, to powiedzenie Marksa stanowi kamień węgielny całego światopoglądu marksistowskie- 
istnienia władzy radzieckiej ograniczano jakiekolwiek przejawy życia religijnego, poddając dyskryminacji ludzi wierzących w szczególności duchownych, których pozbawiono praw politycznych. Głosząc wolność sumienia i wyznania, wprowadzono zakaz organizowania stowarzyszeń religijnych, zgromadzeń i kongresów oraz wszelkiej działalności duszpasterskiej $^{44}$. Sformułowane na obszarze Związku Radzieckiego założenia wcielone zostały w tzw. bloku państw socjalistycznych (Polska, Czechosłowacja, Węgry, Rumunia, Bułgaria, NRD). Warto jednak zauważyć, że w praktyce stosowanie zasady rozdziału kościoła od państwa rozumiane było i realizowane w sposób wysoce zróżnicowany ${ }^{45}$. Różnice te dotyczyły

go w sprawie religii”. Według Lenina „materializm dialektyczny jest nieustannie ateistyczny, ostatecznie wrogi każdej religii”. W. I. Lenin, Dzieła, t. 15, s. 397. W innym miejscu Lenin stwierdzał: „Religia jest jedną z odmian ucisku duchownego, który wszędzie dławi masy ludowe, przytłoczone wieczną pracą na innych, biedą i osamotnieniem [...]. Religia - to opium dla ludu - to rodzaj duchownej gorzałki, w której niewolnicy kapitału topią swe ludzkie oblicze, swoją potrzebę życia, które by choć trochę było godne człowieka” - Socjalizm a religia, w: Dzieła, t. 10, s. 71-72; „Partia dąży do całkowitego rozerwania więzi między klasami wyzyskiwaczy a organizacją propagandy religijnej, jak również do faktycznego wyzwolenia mas pracujących od przesądów religijnych, organizując $\mathrm{w}$ tym celu jak najszerszą propagandę naukowo-oświatową i antyreligijną". Zob. Projekt programu RKP (b), w: Dzieła, t. 29, s. 119. Wskazaniami były też twierdzenia Fryderyka Engelsa, który głosił: „,hcemy [...] przywrócić człowiekowi tę treść którą stracił przez religię; chcemy mu ją przywrócić, nie jako treść boską, lecz ludzka, a to przywrócenie sprowadza się po prostu do obudzenia jego samowiedzy [...]". K. Marks, F. Engels, Dzieła, t, 20, s. 352.

${ }^{44} \mathrm{~W}$ kwestii tej zob. apologetyczne i afirmujące model radziecki rozważania M. T. Staszewskiego, Państwo a Kościół w ZSRR, w: Wolność sumienia. Szkice i polemiki, Warszawa 1973, s. 71 i n.; tenże, Wolność sumienia w ZSRR, „Zeszyty Argumentów" 1967, nr 5, s. 24; W. Mysłek, M. T. Staszewski, Polityka wyznaniowa. Tło, warunki, realizacja, Warszawa 1975, s. 113-120; Zarys dziejów religioznawstwa, red. J. Keller, Warszawa 1988, s. 42-92; por także: E. Grzelak, Stosunek państwa socjalistycznego do religii, wierzeń religijnych obywateli oraz kościolów i zwiazków wyznaniowych, w: Wybrane problemy marksistowskiego religioznawstwa, Warszawa 1972, s. 72; T. M. Jaroszewski, Lenin a problemy polityki wyznaniowej, „Euhemer” 1960, nr 5-6, s. 43; D. Kułakowska, M. Nowaczyk, Religia jako zjawisko społeczne, w: Problemy religii i laicyzacji, Warszawa 1967 (wyd. 2 - 1970), s. 38; D. Kułakowska, M. Nowaczyk, Marksistowsko-leninowska teoria religii, w: Problemy religii i laicyzacji, Warszawa 1971, s. 12; A. Nowicki, Lenin o religii, „Euhemer” 1960, nr 5-6, s. 18; Z. Poniatowski, Lenin a religioznawstwo, „Euhemer” 1960, nr 5-6, s. 32; W. Mołczanow, C. Seruga, Wolność wyznania, Moskwa 1985, s. 6-28.

${ }^{45}$ M. Winiarczyk-Kosakowska, Ustawy III Rzeczpospolitej Polski o stosunku państwa do Kościołów chrześsijańskich, Warszawa 2004, s. 39. 
nie tylko polityki poszczególnych państw, lecz w ramach poszczególnych państw także w różnych okresach historycznych. Warto zauważyć, że koncepcja ścisłego oddzielenia kościoła od państwa w modelu radzieckim była realizowana także w niektórych państwach niesocjalistycznych np. w Meksyku. Niekiedy zaś w niektórych państwach nieeuropejskich formułowano zakaz funkcjonowania wszelkich kościołów chrześcijańskich, czasami zaś nakładano na kościoły zakaz wszelkich poczynań politycznych $^{46}$. Model radziecki zdaje się równo traktować wszystkie kościoły i wyznania w tym także te, które należą do mniejszości. W praktyce jednak władze poszczególnych państw prowadziły dość zróżnicowaną politykę, starając się „wygrywać” animozje i nieporozumienia między poszczególnymi kościołami i wyznaniami. Dlatego czasem w niektórych państwach uprzywilejowano tzw. kościoły narodowe lub ewangelickie. Kościół rzymskokatolicki lub prawosławny z racji tego, iż posiadały centralne ośrodki decyzyjne poza granicami konkretnych państw poddawane były szczegółowszej kontroli, z drugiej strony niektórym związkom wyznaniowym odmawiano prawa do prowadzenia działalności właśnie $\mathrm{z}$ tej racji, iż uznając, że posiadają one ośrodki decyzyjne poza granicami państwa (tzw. świadkowie Jehowy). Wyznawców tych religii dotykały rozmaite restrykcje łącznie z tym, że ponosili oni kary za samą przynależność do związku wyznaniowego, bądź też za odmowę służby wojskowej.

System wzajemnej niezależności państwa od kościoła występuje jako model separacji czystej (amerykański) oraz model separacji skoordynowanej (niemiecki). Model amerykański z punktu widzenia legislacyjnego osadzony jest $\mathrm{w}$ treści art. 6 ust. 3 in fine, w którym stwierdzono, iż ,żadne kryteria religijne nie będą miały znaczenia przy obsadzaniu jakiegokolwiek urzędu lub funkcji publicznych pełnionych w imieniu Stanów Zjednoczonych". Oraz w tekście zdania pierwszego Pierwszej Poprawki do Konstytucji, w myśl której „Kongres nie będzie stanowił żadnych ustaw traktujących jakieś wyznanie jak religie państwową, lub zaka-

46 Taka sytuacja wystapiła w Tunezji, kiedy doszło do zawarcia 27 czerwca 1964 r. modus vivendi między Watykanem a Tunezją. W akcie tym Kościół rzymskokatolicki otrzymał osobowość prawną, uznano jego organizację wewnętrzną, zaakceptowano możliwość prowadzenia nauczania i spełniania obrzędów w miejscach kultu, prawo publikacji dokumentów związanych z jego działalnością, natomiast zabroniono wszelkich poczynań i działalności politycznych w Tunezji, a zasięg możliwości pełnienia kultu poddano nadzorowi państwa. Zob. tekst Conventio (Modus Vivendi) Inter Apostolicae Sedem et Tunetem Republicam, ,Acta Apostolicaee Sedis” 1964, nr 15. 
zujących swobodnych praktyk religijnych" ${ }^{\text {"47 }}$. Pierwsza Poprawka w tej sytuacji z jednej strony zakazuje nadania jakiejkolwiek religii charakteru religii państwowej, a w konsekwencji nie pozwala na ingerencję Kongresu w sprawy wewnętrzne poszczególnych religii i wyznań (klauzula no establishment of religion), z drugiej strony zabrania ograniczania wolności religijnej poszczególnych obywateli, gwarantując jednocześnie wolność spełniania praktyk religijnych w życiu prywatnym i publicznym (klauzula free exercise of religion). Po ratyfikacji Pierwszej Poprawki do Konstytucji powstał problem, czy jej moc obowiązująca dotyczy tylko władz federalnych, czy rozciaga się na władze wszystkich stanów. Dopiero XIV Poprawka do Konstytucji, uchwalona w 1868 r., wyraźnie rozciagnęła obowiązywalność Pierwszej Poprawki na całe Stany Zjednoczone. W literaturze podkreśla się, że wolność religijna przysługuje zarówno poszczególnym obywatelom, jak i związkom wyznaniowym ${ }^{48}$. Jakkolwiek ani w Konstytucji Stanów Zjednoczonych, ani w tekście Poprawki nie pojawiło się słowo „rozdział”, to jednak w orzecznictwie Sądu Najwyższego Stanów Zjednoczonych dokonującego interpretacji zasad konstytucyjnych, ale także w orzeczeniach sądów powszechnych mowa jest wyraźnie $\mathrm{o}$,ścianie separacji” (wall of separation) ${ }^{49}$. Sąd Najwyższy USA, starając

${ }^{47}$ Konstytucja Stanów Zjednoczonych Ameryki, tłum. i wstęp A. Pułło, Warszawa. Zob. Prawa czlowieka w Stanach Zjednoczonych, red. L. Pastusiak, Warszawa 1985, s. 85; Instytucje polityczno-prawne Stanów Zjednoczonych Ameryki, red. W. Sokolewicz, Wrocław-Warszawa-Kraków-Gdańsk 1977, s. 112; J. Wróblewski, Zagadnienia aksjologii politycznej w amerykańskiej teorii prawa, w: W. Lang, J. Wróblewski, Sprawiedliwość spoleczna i nieposhuszeństwo obywatelskie $w$ doktrynie politycznej USA, Warszawa 1984, s. 97, 2002, s. 53 i 55.

48 Zob. Prawa czlowieka w Stanach Zjednoczonych, red. L. Pastusiak, Warszawa 1985, s. 85; Instytucje polityczno-prawne Stanów Zjednoczonych Ameryki, red. W. Sokolewicz, Wrocław-Warszawa-Kraków-Gdańsk 1977, s. 112; J. Wróblewski, Zagadnienia aksjologii politycznej w amerykańskiej teorii prawa, w: W. Lang, J. Wróblewski, Sprawiedliwość spoleczna i niepostuszeństwo obywatelskie w doktrynie politycznej USA, Warszawa 1984, s. 97.

49 Jednym z ważniejszych ustrojowych uprawnień sądów powszechnych w USA jest ich kompetencja do orzekania o zgodności prawa stanowionego z Konstytucja Unii oraz z konstytucjami stanowymi. Instytucję tę określa się jako judical review. Uprawnienie to nie zostało także przyjęte - jak wiele innych elementów amerykańskiego systemu prawnego - z tradycji brytyjskiej. Nie ma tam bowiem ani odpowiedniej instytucji prawnej umożliwiającej sądom tego typu aktywność, ani też zwyczajów w tym zakresie. Obowiązuje tam zasada, że to co parlament postanowi, jest ipso facto prawem zgodnym z konstytucją. Zob. A. Pułło, Wspótczesne ustroje państwowe. Wielka Brytania, Gdańsk 1983, rozdz. III: Źródła prawa konstytucyjnego, s. 84; T. Langer, 
się dociec treści Pierwszej Poprawki przyjął - opierając się na wypowiedzi T. H. Jeffersona - iż zmierza ona do wprowadzenia rozdziału kościoła od państwa. Rozdział ten chce Sąd Najwyższy pojmować jako eliminację wszelkiej ingerencji państwa, zarówno w sprawy dotyczące wszystkich jak i poszczególnych kościołów oraz zagwarantowanie tym kościołom niezależności od państwa w kierowaniu swoimi sprawami. Nie pozwala to władzom państwowym na tworzenie jakichkolwiek organizacji o charakterze religijnym. Tworzenie kościołów i przynależność do nich pozostawiona została inicjatywie obywateli ${ }^{50}$. W praktyce kościoły cieszą się jednak pewnymi przywilejami, chociażby w prawie podatkowym. Nie są więc traktowane identycznie jak stowarzyszenia czy korporacje prawa prywatnego ${ }^{51}$. Kościoły w Stanach Zjednoczonych mogą prowadzić działalność związaną z kultem, nauczaniem i wychowaniem, w tym także szkolnictwo prywatne o charakterze wyznaniowym wszystkich szczebli i z tej racji otrzymywać pomoc finansową na pokrycie wydatków, ale tych tylko, które mają cel świecki. Sąd Najwyższy USA opowiadał się jednak przeciwko nauczaniu religii, odmawianiu modlitwy, medytacjom religijnym mimo dobrowolności uczestnictwa. Za dopuszczalne natomiast uznano

Stany w USA. Instytucje - praktyka - doktryna, Koszalin 1997, s. 297; R. Małajny, Mór separacji-państwo a kościót w stanach Zjednoczonych Ameryki, Katowice 2002, passim.

50 Sąd Najwyższy Stanów Zjednoczonych w sprawie Everson przeciwko Board of Education (1947), uznał, że treść Pierwszej Poprawki do Konstytucji oznacza, że ani władze federalne, ani państwowe nie mogą stanowić prawa, które gwarantowałoby pomoc finansową jednej religii lub wszystkich religii. Nie mogą też nakładać podatku w jakiejkolwiek wysokości na instytucje kościelne lub na działalność mającą charakter religijny. Zob. L. Manning, The law of Church-State relations, ST. Paul, Minn 1981, s. 134-144. W sprawie Walz przeciwko Tax Commision (1970) Sąd Najwyższy Stanów Zjednoczonych uznał za zgodną z Konstytucją instytucję zwalniania nieruchomości należących do organizacji kościelnych od opodatkowania, jeżeli ich dochody przeznaczone są na cele kultu. Kościoły zostały więc zwolnione od opodatkowania ze względu na to, iż nie prowadzą działalności zarobkowej (non profit organisations). Racją takiego przywileju jest uznanie, iż wywierają one korzystny wpływ na życie społeczne. Racją zwolnienia kościołów od opodatkowania jest również troska o to, aby nie nastapiło „uwikłanie się państwa w sprawy religijne”. Zob. R. M. Małajny, Konstytucjonalizacja zasady rozdziału Kościoła od państwa i jej ewolucja w USA, w: Konstytucja USA 1787-1987, Warszawa 1987, s. 323.

51 J. Godlewski, Wolność sumienia i rola zwiazków wyznaniowych w Stanach Zjednoczonych Ameryki, w: Instytucje i doktryny polityczno-prawne Stanów Zjednoczonych Ameryki (zagadnienia wybrane), red. W. Sokolewicz, Wrocław 1974, s. 426-428, 431-432, 434-441. 
w latach 80. i 90. XX w. w orzecznictwie Sądu Najwyższego zakładanie przez uczniów publicznych szkół średnich i studentów uniwersytetów stanowych, stowarzyszeń religijnych i odbywanie przez członków tych stowarzyszeń spotkań w pomieszczeniach szkolnych. Za zgodne z Konstytucją i Pierwszą Poprawką uznaje się natomiast instytucję kapelanów opłacanych z funduszy państwowych w wojsku, policji, zakładach karnych, w Białym Domu, Kongresie, legislaturze stanowej, domach opieki, szpitalach. Podobnie nie narusza tych zasad składanie przysięgi na biblię przy obejmowaniu urzędów, stanowisk i funkcji publicznych, składaniu zeznań w sądzie, odmawianie modlitwy przez kapelana w legislaturze. Tego rodzaju praktyki oznaczane są w literaturze amerykańskiej jako religia obywatelska (civil religion) ${ }^{52}$. Model amerykański nie ma charakteru ani antyreligijnego, ani areligijnego. Religia obecna jest w życiu społecznym i pojmowana jako wspólne dziedzictwo narodu amerykańskiego. Rozdział państwa od kościoła nie oznacza w gruncie rzeczy rozdziału polityki od religii. Rozdział ten jest jedynie wzajemnym rozdzieleniem od siebie instytucji w wyniku czego, instytucje kościelne nie mają bezpośredniej więzi z państwem. Zasada instytucjonalnego rozdziału oraz jego ścisłe stosowanie zapobiegło powstawaniu antagonizmu na tle religijnym ${ }^{53}$. Po drugiej wojnie światowej zaobserwowano odchodzenie od tradycyjnie pojmowanej religijności. Zakwestionowano także wiele obowiązujących aksjomatów, tradycyjną moralność, moralistyczny idealizm oraz teizm judeochrześcijański. Laicyzacji życia sprzyjała także decyzja Sądu Najwyższego uznającego w 1963 r. ceremonie religijne w szkołach publicznych za niezgodne z Konstytucją. W modelu tym problem mniejszości religijnych nie pojawia się, podobnie jak kwestia wyznań niechrześcijańskich, aczkolwiek można stwierdzić, iż wyznania chrześcijańskie mimo wszystko w ramach religii obywatelskiej mają lepszą pozycję chociażby z racji formy przysięgi składanej przy różnych okazjach.

Model separacji skoordynowanej (niemiecki). Model ten noszący czasem nazwę niemieckiego modelu państwa świeckiego ukształtował się w Niemczech po pierwszej wojnie światowej. Podstawąjego była Konsty-

52 E. M. West, A proposal neutral definition of ,, civil religion”, ,,Journal of Church and State" 22 (1980), nr 1, s. 39; S. E. Ahlstrom, Religious History of the American People, New Haven-London 1972, s. 7-11.

M. Gołębiowski, Dzieje kultury Stanów Zjednoczonych, Warszawa 2006, s. 152; W. S. Hudson, Religion in America. An Historical Account of the Development of American Religious Life, 4th ed., New York-London 1987. 
tucja Republiki Weimarskiej z 11 sierpnia 1919 r., w której stwierdzono, że „kościół państwowy nie istnieje” (Es besteht keine Staatskirche art. 137 $\S 1)$. Rozwiązanie to przyjmowane dość przychylnie po dzień dzisiejszy w opracowaniach katolickich uderzało z jednej strony w Kościoły protestanckie, z drugiej strony stanowiło rewizję jurysdykcjonalizmu. Uprawnienia władców poszczególnych landów niemieckich, które weszły w skład Republiki Weimarskiej, wobec Kościołów protestanckich, zostały tym samym zniesione. Oryginalność modelu niemieckiego sprowadzała się do tego, że ustrojodawca postanowił uregulować status nie tylko Kościoła rzymskokatolickiego, czy dominujących na niektórych obszarach Kościołów protestanckich, lecz wszystkich kościołów, związków wyznaniowych i wspólnot światopoglądowych istniejących na terenie Republiki Weimarskiej. Kościoły i związki wyznaniowe zostały uznane za korporacje prawa publicznego - jeśli były nimi dotychczas - posiadające w obrocie prawnym zespół przywilejów m.in. w prawie podatkowym odróżniający ich od korporacji prawa prywatnego (art. $137 \S 5)^{54}$. Innym wspólnotom religijnym jak stwierdzono w Konstytucji należy przyznać, na ich wniosek, te same prawa, jeśli ich ustrój i liczba członków dają gwarancje trwałości. W Konstytucji stwierdzono jednoznacznie: „zapewnia się wolność zrzeszania we wspólnoty religijne" (w dosłownym tłumaczeniu w stowarzyszenia religijne - Der Zusammenschluß von Religionsgesellschaften) ${ }^{55}$. Zaznaczono także, że jeśli kilka tego rodzaju wspólnot religijnych połączy się w jeden związek to i ten związek jest również korporacją publiczno-prawną. Jednocześnie zawarowano, że łączenie się wspólnot religijnych na obszarze Rzeszy nie podlega żadnym ograniczeniom. Każda wspólnota ma regulować swoje sprawy i zarządzać nimi samodzielnie w ramach prawa wewnętrznego ${ }^{56}$. Ma także obsadzać swoje urzędy bez współdziałania państwa bądź gminy cywilnej. Wspólnoty religijne z mocy Konstytucji (art. 137 § 4) nabywają zdolność prawną stosownie do ogólnych przepisów prawa cywilnego. W Konstytucji stwierdzono,

54 S. Fundowicz, Osobowość publicznoprawna wspólnot religijnych w Niemczech, w: Współczesne problemy prawa publicznego, t. I, Lublin 1999, s. 55-60.

55 Tekst Konstytucji cyt. za Ustawa zasadnicza (konstytucja) Republiki Federalnej Niemiec z 23 maja 1949, red. wprowadzenie i weryfikacja L. Janicki, Poznań 1997, s. $290-295$.

56 M. Kosek, Konstytucyjne zasady niemieckiego prawa wyznaniowego, w: Prawo wyznaniowe w systemie prawa polskiego. Materiały I Ogólnopolskiego Sympozjum Prawa Wyznaniowego (Kazimierz Dolny 14-16 stycznia 2003), red. A. Mezglewski, Lublin 2004, s. 103-114. 
że są one konsekwencją przyjętego w Konstytucji założenia, że każdy kościół ma charakter podmiotu autonomicznego i zdolnego do stanowienia norm wewnętrznych oraz samodzielność w decydowaniu o swojej działalności na obszarze państwa. W literaturze podkreślano, że stosunki między państwem a kościołami mogą być rozstrzygane bądź w drodze negocjacji, bądź w drodze dwustronnych układów. Obywatelom zostało zagwarantowane prawo do wolności religijnej w wymiarze indywidualnym (art. 136). Status kościołów miały określić - zgodnie z art. $10 \S 1$ i art. 12 oraz art. $137 \S 8-\mathrm{i}$ w efekcie określiły, ustawy w poszczególnych landach (Soweit die Durchführung dieser Bestimmungen eine weitere Regelung erfordert, liegt diese der Landesgesetzgebung ob.). Niektóre z nich wydały takie ustawy. Uczyniła to (Bawaria ustawa z 28 stycznia 1926 r., Witenbergia ustawa z 29 stycznia 1924 r., Saksonia ustawa z 17 lipca 1926 r.). Prusy ustawą z 8 kwietnia 1924 r. odnoszącą się do kościołów ewangelickich zawarowały władzom administracyjnym prawo kontroli państwa nad erekcją nowych kościołów, ale także nad administracją kościelną. Stało to się źródłem konfliktu państwa z kościołami protestanckimi. W okresie międzywojennym doszło do zawarcia nie tylko konkordatu między Stolicą Apostolską a Niemcami, lecz także z poszczególnymi landami. Podobne do konkordatów układy (umowy państwowo-kościelne - Staatskirchenveträge) podpisywały z poszczególnymi landami także kościoły protestanc$\mathrm{kie}^{57}$. W literaturze uznaje się, że najważniejszym elementem separacji skoordynowanej w Niemczech stało się uznanie autonomii związków wyznaniowych. Do najważniejszych cech tych autonomii zaliczono stwierdzenie, że kościoły i związki wyznaniowe mają zdolność do rządzenia się własnym prawem oraz że wewnętrzna sfera prawna związków wyznanio-

57 Umowy państwowo-kościelne z Kościołem ewangelickim, jak również umowy zawierane z diecezjami katolickimi, są umowami sui generis, ale są traktowane jako kategoria zbliżona do umów międzynarodowych. Umowy te względnie porozumienia regulują również stosunki z wieloma mniejszymi wspólnotami wyznaniowymi. Pod względem treści zazwyczaj dotyczą one współpracy pomiędzy państwem a biskupami, gwarancji i warunków edukacji religijnej w szkołach publicznych, funkcjonowania wydziałów teologicznych na uniwersytetach, pracy kapelanów wojskowych, pozycji kościoła w sferach publicznych. Zob. J. Krukowski, Konstytucyjne podstawy stosunków między państwem a Kościołami w Republice Federalnej Niemiec, w: Divina et humana. Księga Jubileuszowa w 65 rocznice urodzin ks. prof. Henryka Misztala, red. A. Dębiński, W. Bar, P. Stanisz, Lublin 2001, s. 107-124. Odnośnie konkordatów zob. Konkordate und Kirchenverträge in der Bundesrepublik Deutschland, red. J. Listl, t. 1-2, Stuttgart 1987, passim. 
wych nie jest w żaden sposób uzależniona od prawodawstwa państwowego $^{58}$. Warto pamiętać, że w myśl art. 136 § 1 Konstytucji Republiki Weimarskiej prawa i obowiązki cywilne oraz obywatelskie nie są przez korzystanie z wolności religijnej ani uwarunkowywane, ani ograniczane. Korzystanie z praw cywilnych i obywatelskich, jak również dostęp do urzędów publicznych, jest niezależne od wyznania religijnego. Nikt także nie może być zobowiązany do ujawniania swych przekonań religijnych (art. $136 \quad \S 3$ ).

Uchwalona po II wojnie światowej Ustawa Zasadnicza Republiki Federalnej Niemiec (Grundgestz für die Bundesrepublik Deutschland) z 23 maja 1949 r. w art. 140 stwierdziła, że postanowienia art. 136-139 i art. 141 Niemieckiej Konstytucji z 11 sierpnia 1919 r. stanowią integralną część tej ustawy. W Konstytucji z 1949 r. stwierdzono w art. 4, iż wolność wyznania, sumienia oraz wolność przekonań religijnych i światopoglądowych jest nienaruszalna (Alle Menschen sind vor dem Gesetz gleich). Zauważono także, że zapewnia się swobodę wykonywanie praktyk religijnych art. $4 \S 2$, a także że uprawnieni do wychowania mają prawo do decydowania o nauce dziecka religii (art. $7 \S 2$ ). Nauka religii w szkołach publicznych w myśl Konstytucji - z wyjątkiem szkół bezwyznaniowych - jest normalnym przedmiotem nauczania. Tak więc Konstytucja z 1949 r. z później wprowadzonymi zmianami nie naruszyła modelu separacji skoordynowanej. System istniejący w Niemczech zakłada neutralność państwa wobec przekonań religijnych i światopoglądowych w znaczeniu pozytywnym. Wynika ona z gwarancji wolności sumienia i wyznania każdej osoby ludzkiej, z zakazu wprowadzenia kościoła państwowego oraz zakazu dyskryminacji lub uprzywilejowania kogokolwiek ze względu na wyznanie. Neutralność ta nie oznacza popierania ateizmu bądź agnostycyzmu $^{59}$.

Wśród krajów zmierzających w kierunku separacji skoordynowanej znaleźć się miała według opinii części badaczy Hiszpania, ustanawiając

58 System relacji między Kościołem a państwem w Niemczech od czasu Republiki Weimarskiej przeszedł pewną ewolucję zmierzającą do nowego typu wzajemnego zbliżenia, które nie implikuje absorpcji, czyli pochłonięcia jednej społeczności przez drugą, ale wspólną koordynację zadań dla dobra wspólnego osoby ludzkiej w kontekście różnych form życia publicznego. Zob. V. P. Mikat, Das kirchenpolitische System. Staat und Kirchen in der Bundesrepublik, Berlin-Erich 1997, s. 202-206.

59 M. Kosek, Wolność religijna $w$ wymiarze pozytywnym i negatywnym na przykładzie orzeczenia Niemieckiego Federalnego Trybunatu Konstytucyjnego z 16 maja 1995, „Studia z Prawa Wyznaniowego” 2000, t. 5, s. 49-50. 
w swojej konstytucji zasadę neutralności religijnej państwa oraz zasadę współdziałania władz publicznych z kościołami i wyznaniami. W Konstytucji wyraźnie stwierdzono, że zapewnia się jednostkom i wspólnotom wolność w sferze ideologii, religii i kultu. A korzystanie z tych wolności podlega tylko takim ograniczeniom, jakie są konieczne dla utrzymania ładu publicznego. W art. 16 ust. 3 Konstytucji stwierdzono wyraźnie: ,żadne wyznanie nie ma charakteru państwowego, a władze publiczne uwzględniają przekonania religijne społeczeństwa hiszpańskiego i utrzymują wynikające z tego stosunki współpracy z Kościołem katolickim i pozostałymi wyznaniami" ${ }^{60}$. Sytuację prawną kościołów reguluje ustawa o wolności religijnej uchwalona w 1980 r., obiecująca zawarcie przez państwo odpowiednich porozumień o współpracy z kościołami, religiami i zarejestrowanymi związkami wyznaniowymi. Porozumienia takie winny zostać zatwierdzone przez parlament. W literaturze stwierdza się, że model hiszpański nie jest przykładem kościoła państwowego, nie jest także modelem państwa wyznaniowego, nie pokrywa się także z modelem rozdziału. Ideą tego modelu jest po pierwsze teza, że związki wyznaniowe powinny być uznane przez państwo, po drugie koncepcja wolności religijnej jako fundamentalna zasada systemu. Ważną sprawą jest także ustalenie pozycji mniejszościowych związków wyznaniowych poprzez stosowne porozumienia. Zauważa się, że jest to „system piramidalny”, który charakteryzuje się tym, że Kościół katolicki uzyskał poprzez konkordaty maksymalne prawa, gdyż jego status regulowany jest umową międzynarodową. Mniejszościowe związki wyznaniowe, które podpisały porozumienia, mają mniejsze prawa, zważywszy, iż ich sytuacja prawna regulowana jest na poziomie ustawy ${ }^{61}$. Na dalszym miejscu znajdują się zarejestrowane związki wyznaniowe, które nie zawarły porozumień. W odniesieniu do tych ostatnich ramy prawne określa ustawa o wolności religijnej z 1980 r. ${ }^{62}$ Według innych model hiszpański to model państwa rozdziału skoordyno-

\footnotetext{
${ }^{60}$ Konstytucja Hiszpanii z 27 grudnia 1978 r., thum. T. Mołdawa, Warszawa 1993, s. 37 .

${ }^{61}$ P. Ryguła, Podstawowe pryncypia hiszpańskiego prawa wyznaniowego, w: Prawo wyznaniowe w systemie prawa polskiego. Materiały I Ogólnopolskiego Sympozjum Prawa Wyznaniowego (Kazimierz Dolny 14-16 stycznia 2003), red. A. Mezglewski, Lublin 2004, s. 115-141.

${ }^{62}$ I. C. Ibán, Państwo i kościót w Hiszpanii, w: Państwo i kościót, s. 165-177; I. Soler, Kościót katolicki w nowej sytuacji politycznej Hiszpanii, w: Religia-tożsamość - Europa, red. i oprac. P. Mazurkiewicz, S. Sowiński, Wrocław-Warszawa-Kraków 2003, s. 200-210.
} 
wanego, rozdziału pozytywnego, bądź model państwa instytucjonalno-świeckiego ${ }^{63}$. Inni zaliczają Hiszpanię do państw świeckich z rozdziałem przyjaznym między państwem a kościołem, bez wyraźnego uznania pozycji prawnej jednego z kościołów ${ }^{64}$. (Na marginesie wypada zauważyć, iż w rozważaniach nad stosunkami między państwami a kościołami i związkami wyznaniowymi wielu autorów wręcz ,sili się”, aby zaproponować własną odmienną od dotychczas stosowanych typologię. Tego rodzaju ujęcia typologiczne, skądinąd może ciekawe, niewiele wnoszą). Mniejszościowe związki wyznaniowe nie cieszą się zasadniczo żadnymi specjalnymi względami. Natomiast we wszystkich ośrodkach dydaktycznych finansowanych przez państwo ze środków publicznych nauka religii katolickiej jest oferowana fakultatywnie, aczkolwiek nauczyciele opłacani są przez państwo. Nauka religii innych związków wyznaniowych jest przeprowadzana tylko wówczas, gdy na takie zajęcia zdecyduje się co najmniej 10 uczniów. Na publicznych uniwersytetach państwowych nie mogą istnieć fakultety teologiczne. Kościół rzymskokatolicki ma prawo prowadzić i prowadzi szereg uniwersytetów. W doktrynie istnieje spór co do tego czy formuła przyjęta w art. 16 Konstytucji pozwala na przyjęcie, że istnieje jedno prawo wyznaniowe gwarantowane w różnych aspektach, czy też trzy odrębne prawa do wolności ideologicznej, religijnej i kultu. Orzecznictwo hiszpańskiego Trybunału Konstytucyjnego niekiedy odnosi się jednocześnie do wspomnianych trzech rodzajów wolności, czasami do wolności religijnej i kultu, kiedy indziej do wolności religijnej i ideologicznej. Wolność religijna rozumiana jest przez Trybunał jako konkretyzacja wolności ideologicznej, a jednocześnie jako podstawowe prawo podmiotowe, które gwarantuje istnienie przekonań, a w konsekwencji respektowanie przestrzeni samookreślenia jednostki. Przestrzeń zewnętrzną swobodnego zachowania jednostki wobec zjawiska religijności wytycza brak przymusu ze strony państwa i grup społecznych ${ }^{65}$. Trybunał Konstytu-

63 Świeckość instytucjonalna ma odnosić się do formalno-prawnej strony organizacji i funkcji organów państwa bez przesądzania o treściach działania tych organów. Przeciwieństwem świeckości formalno-prawnej ma być, w myśl tej koncepcji, świeckość integralna obejmująca w pewną nierozerwalną całość formalno-prawną ilościowy aspekt formowania i działalności organów i urzędów państwowych. Zob. A. Czohara, Konstytucyjne ramy hiszpańskiego modelu wolności religijnej, w: Religia - tożsamość - Europa, red. i oprac. P. Mazurkiewicz, S. Sowiński, Wrocław-Warszawa-Kraków 2003, s. 190-195.

64 K. Orzeszyna, Podstawy relacji między państwem a kościołami, s. 180.

65 M. Safjan, Wolność religijna w konstytucjach państwa europejskich, „Kultura i Prawo”, t. III: Materiaty III Międzynarodowej Konferencji na temat Religia i wolność 
cyjny stwierdzał, że ,zasada niewyznaniowego oraz świeckiego charakteru państwa stanowi przeszkodę do tego, aby wyznania religijne, realizując swe własne cele były określane jak instytucje państwowe i zajmowały taką samą pozycję prawną. Podkreśla się także, że władza publiczna musi brać pod uwagę opinię religijną społeczeństwa hiszpańskiego. Niektórzy zdają się wywodzić stąd, iż nie musi ona brać pod uwagę postaw ateistycznych i agnostycznych ${ }^{66}$. Konstatacja ta wydaje się jednak błędna, gdyż negowanie religii także jest opinią wyrażaną wobec tego zjawiska. Warto zauważyć, że ostatnie rozwiązania legislacyjne Hiszpanii otwierające drogę do legalnej aborcji i zapłodnień in vitro naraziły ten kraj na gwałtowne ataki hierarchii katolickiej i to najwyższych jej dostojników, co niekoniecznie zaowocuje zmianą przyjętych rozwiązań prawnych, a wręcz przeciwnie, może przyczynić się do wzrostu tendencji laicyzacyjnych ${ }^{67}$.

W kierunku modelu separacji skoordynowanej zdaje się zmierzać system prawny Austrii, który opiera się na dwóch zasadach. Po pierwsze - na prawie indywidualnej wolności wyznania i przekonań filozoficznych. Po drugie - na gwarancji wolności aktywności publicznej związków wyznaniowych. W Austrii nie istnieje kościół państwowy. Na poziomie instytucjonalnym kościół i państwo są rozdzielone. Państwo akceptuje działalność kościołów i związków wyznaniowych na arenie publicznej i stara się ująć w ramy prawne działalność religii w życiu społecznym - w tym zakresie, w którym nie wykonuje ono swych funkcji. Traktując kościoły i związki wyznaniowe jako swoisty podmiot prawa publicznego nie postrzega jednak państwo religii jako kwestii prywatnej. Kościoły i związki wyznaniowe dzielą się na uznane historycznie, których status regulowany jest odrębnie w drodze oddzielnych ustaw (taki status ma Kościół katolicki, Kościół ewangelicko-augsburski, Kościół helwecki, Kościół prawosławny - grecki, Kościół ormiańsko-apostolski, Kościół syryjsko-prawosławny, Kościół koptyjsko-prawosławny oraz wielonurtowe wspólnoty izraelickie oraz islamskie) i uznane w oparciu o żądanie wyznawców. Na podstawie ustawy uznane zostały w drodze rozporządzeń: Kościół starokatolicki, Kościół metodystyczny, Kościół Jezusa Chrystusa Świętych Dni Ostat-

religijna w Unii Europejskiej, Warszawa 2-4 września 2002, red. J. Krukowski, O. Theisen, Lublin 2003, s. 52-53.

${ }^{66}$ K. Orzeszyna, Podstawy relacji między państwem a kościołami, s. 180-182.

67 M. Stasiński, Polityczno-kulturowy kontekst sporów państwo - Kościól we współczesnej Hiszpanii, w: Religia - tożsamość - Europa, red. i oprac. P. Mazurkiewicz, S. Sowiński, s. 198-200. 
nich, Kościół nowoapostolski, Austriackie Religijne Stowarzyszenie Buddystyczne $^{68}$.

Warto zauważyć, iż całkowicie zapomniana została koncepcja H. Świątkowskiego, który badając historię stosunków wyznaniowych w relacji państwo-kościół wyróżnił pięć systemów. Cztery z nich pokrywają się z omówionymi wyżej. Natomiast godzi się przypomnieć system legalizmu państwowego, który według oceny H. Świątkowskiego miał istnieć w Polsce w okresie międzywojennym. Cechami jego miały być po pierwsze - suwerenność państwa wobec wszystkich związków wyznaniowych (pewne odchylenie od tej zasady istniało - zdaniem H. Świątkowskiego - w stosunku do Kościoła rzymskokatolickiego, który zajmował pozycję partnera równorzędnego z państwem, co potwierdza konkordat i praktyka jego wykonania). Po drugie - korzystanie przez związki wyznaniowe ze względnego samorządu, w zakresie ściśle określonym przez ustawodawstwo państwowe (w Polsce przedwojennej - kodeks prawa kanonicznego oparty na konkordacie oraz statutach wewnętrznych nierzymskokatolickich związków wyznaniowych). Po trzecie - dowolność w różnym traktowaniu przez państwo poszczególnych związków wyznaniowych, wyrażająca się w więcej lub mniej rygorystycznym stosowaniu nadzoru nad nimi, w subsydiowaniu wyznań przez państwo w ramach jego budżetu, w zlecaniu funkcji urzędowych $\mathrm{z}$ ramienia państwa itp. ${ }^{69}$

\section{Forma regulacji stosunków wyznaniowych jako podstawa klasyfikacji państw}

W niektórych ujęciach dążąc do określania systemu relacji między państwem a związkami wyznaniowymi, w gruncie rzeczy między państwem a dominującym wyznaniem przeprowadza się klasyfikację, nie tyle relacji między państwem a kościołem, bądź kościołami, co klasyfikację państw ze względu na ich stosunek do religii, zazwyczaj do tej religii, która jest

68 R. Potz, Państwo i kościót w Austrii, w: Państwo i kościót, s. 11-30.

69 H. Świątkowski, Wyznaniowe prawo państwowe, Warszawa 1962, s. 10 i n. Por. także: J. Sawicki, Historia stosunku kościoła do państwa, Warszawa 1947, s. 208-214; F. Bączkowicz: Prawo kanoniczne - Podręcznik dla duchowieństwa, wyd. 3, Opole 1957, s. 114 i n.; J. Jurkiewicz, Recenzja ksiażki H. Światkowskiego pt. Wyznaniowe prawo państwowe, „Państwo i Prawo” 1963, z. 5-6, s. 956 i n.; T. Langer, Państwo a nierzymskokatolickie zwiqzki wyznaniowe w Polsce Ludowej, Poznań 1967, s. 16 i n. 
dominująca w danym państwie. Klasyfikacje te odnosi się zazwyczaj do współczesnych systemów relacji między państwami a wyznaniami. Podstawą ich są kryteria merytoryczne, do których zalicza się zasady ustrojowe państwa oraz formalne pojmowane jako sposoby regulacji tych stosunków w płaszczyźnie prawnej. Zwolennicy tej typologii przy użyciu pierwszego z kryteriów wyróżniają państwa wyznaniowe i państwa świeckie. Z uwagi na drugie kryterium wyróżniają państwa konkordatowe i bezkonkordatowe ${ }^{70}$. Warto zauważyć, że typologia ta uwzględnia w swej treści część systemów i modeli ukształtowanych historycznie ${ }^{71}$.

W ramach państw wyznaniowych zwolennicy wspomnianej typologii wyróżniają dwa podsystemy: wyznaniowości tradycyjnej, czyli zamkniętej oraz wyznaniowości zmodernizowanej, czyli otwartej. Dla państw wyznaniowych o charakterze tradycyjnym (zamkniętym) znamiennym jest po pierwsze - afirmacja określonej doktryny religijnej, jako jedynej prawdziwej; po drugie - formalne uznanie w ustawie lub umowie konkordatowej jednej religii lub jednego z kościołów jako religii oficjalnej, bądź jako kościoła państwowego; po trzecie - subwencjonowanie określonej religii czy też działalności określonego kościoła z funduszy publicznych; po czwarte - formalny zakaz wyznawania innych religii poza religią oficjalną. W chwili obecnej w Europie nie ma państwa wyznaniowego w wersji tradycyjnej, czyli zamkniętej. Za czasów gen. Franco, takim państwem była Hiszpania. Można jednak stwierdzić, że w dużej mierze swoistym państwem wyznaniowym jest Watykan (Città del Vaticano), aczkolwiek przyznać należy, że w państwie tym nie istnieje formalny zakaz wyznawania innej religii niż rzymskokatolicka. Na świecie istnieją państwa wyznaniowe w wersji tradycyjnej. Są to państwa islamskie: Iran, Arabia Saudyjska, Sudan. W państwach tych za zmianę przynależności wyznaniowej grozi kara śmierci.

Do państw wyznaniowych o charakterze zmodernizowanym (otwartym) zalicza się państwa, które uznają jedną religię lub jeden z kościołów jako religię narodową bądź jako kościół narodowy, bądź państwowy z racji historycznej, najczęściej z racji wkładu tego kościoła w kulturę narodową, bądź z przyczyn socjologiczno-demograficznych - lub, że do określonego kościoła bądź wyznania przynależy większość danego społeczeństwa. Religia narodowa zwykle jest subwencjonowana z funduszy

70 Typologię taką proponuje J. Krukowski, Polskie prawo wyznaniowe, s. 25-38.

71 Omówienie zob. wyżej podrozdział 1. 
państwowych. Państwo wyznaniowe w tej wersji najczęściej rezygnuje $\mathrm{z}$ afirmacji jednej religii jedynie prawdziwej i gwarantuje wolność religijną dla wyznawców wszystkich religii. Różnica między państwami wyznaniowymi w wersji tradycyjnej i otwartej zasadza się na tym, że w tej drugiej wersji państwo nie zajmuje stanowiska w sprawie prawdziwości religii, pozostawiając to wiernym i godząc się na możliwość wyboru przez wiernych religii bądź światopoglądu. Związki między państwem a religią uznawaną za oficjalną, bądź państwową, wynikają najczęściej z dziejów określonego państwa i z roli, jaką w tych dziejach spełniał jeden z kościołów, bądź związków wyznaniowych. W chwili obecnej w Europie państwa wyznaniowe w wersji otwartej to: Republika Cypru, Królestwo Danii, Republika Finlandii, Republika Grecji, Republika Malty, Zjednoczone Królestwo Wielkiej Brytanii i Irlandii Północnej ${ }^{72}$. Państwa świeckie to państwa oparte na zasadzie separacji, czyli oddzielenia kościoła od państwa. Zasada ta jest niejednoznaczna i bardzo elastyczna. W literaturze wskazuje się, że nie ma jednego modelu państwa świeckiego, lecz istnieją różne jego odmiany obejmujące szeroką skalę rozpiętości założeń określających politykę państwa wobec religii i instytucji kościelnych. (Począwszy od skrajnego agnostycytymu - czyli ignorowania wyznań religijnych i otwartej wrogości państwa wobec kościoła, aż do współpracy opartej na umowie konkordatowej) ${ }^{73}$. Wyróżnia się przy tej okazji amerykański model separacji czystej oraz modele separacji wrogiej w dwóch wersjach, francuskiej - skrajnie liberalnej i radzieckiej - totalitarnej oraz niemiecki model separacji skoordynowanej ${ }^{74}$. Warto zauważyć, że jakkolwiek z punktu widzenia systemowego prezentowana koncepcja opiera się na innych założeniach, to jednak modele, które wyróżnia się w jego treści występowały także w klasyfikacji omówionej wyżej, z tym że model francuski i model radziecki ujmowany był w ramach systemu rozdziału kościoła od państwa, a model amerykański separacji czystej i model niemiecki separacji skoordynowanej $\mathrm{w}$ ramach systemu wzajemnej niezależności państwa i kościoła.

Nie ma natomiast odpowiednika, we wcześniej zrelacjonowanej klasyfikacji podział oparty o kryteria formalne, w myśl którego wyróżniano państwa modelu konkordatowego oraz państwa bezkonkordatowe. Warto

72 Charakterystykę relacji między władzami państwowymi a kościołami w tych państwach dokonano wyżej w podrozdziale 1.

73 J. Krukowski, Polskie prawo wyznaniowe, s. 27.

74 Ibidem, s. 27-31. 
zauważyć, że taka koncepcja prezentowana zresztą w myśli katolickiej jest silnie uwarunkowana katolikocentrycznym sposobem widzenia. Afirmujący tę klasyfikację zdają się nie dostrzegać, że poza Kościołem katolickim mogą istnieć i istnieją inne kościoły i wyznania, traktuje Kościół rzymskokatolicki jako jedyny punkt odniesienia państwa do religii. $\mathrm{W}$ istocie rzeczy podział ten odnosi się więc tylko do stosunków między państwami, zwłaszcza z kręgu Europy, a Stolicą Apostolską. Podstawową nieścisłością, żeby nie powiedzieć błędem, jaki popełniany jest przy okazji wyróżniania państw konkordatowych i bezkonkordatowych jest twierdzenie, iż konkordat jest umową między państwem a kościołem ${ }^{75}$. $\mathrm{W}$ istocie konkordat to umowa między państwem a Stolicą Apostolską, określająca status prawny Kościoła rzymskokatolickiego i katolików w danym państwie, kompetencje organów kościelnych i państwowych w sprawach interesujących obie strony ${ }^{76}$. Przyznać jednak należy, że po

75 Przedmiot konkordatów jest dość złożony, z przeprowadzonych analiz wynika, że dotyczą one trzech grup spraw: doczesnych (res temporales), duchownych (res spirytuales) i tak zwanych spraw mieszanych (res mixtae), te ostatnie są to sprawy, które ze względu na swój charakter podlegają kompetencji obu stron. Wśród spraw tych wskazuje się prawodawstwo małżeńskie, szkolne, kompetencje sądów cywilnych i karnych w stosunku do osób duchownych oraz problem dni świątecznych. Konkordaty jako układy zawierane między państwem a Stolicą Apostolską nie regulują i nie mogą regulować sprawy granic politycznych, należących do wyłącznej kompetencji państw jako suwerennych podmiotów prawa międzynarodowego. W odniesieniu do granic państwowych konkordaty są „umowami międzynarodowymi o charakterze wtórnym", tzn. że jeżeli regulują sprawy granic diecezji w ramach politycznych granic danego państwa, to dotyczą czegoś, co już zostało przesądzone i uregulowane innymi aktami prawnymi o charakterze układów międzypaństwowych w sensie ścisłym. Granice państw nie podlegają kompetencji Stolicy Apostolskiej. Zwierzchni organ Kościoła katolickiego, zawierając układ z danym państwem uznaje aktualne status quo granic danego państwa i dostosowuje granice diecezji i innych jednostek administracyjnych Kościoła do granic już istniejących - czy to na mocy układów, czy na mocy stanu faktycznego. Zob. T. Bertone, Analiza i ocena umów między Kościołem a wspólnotami politycznymi, „Kościół i Prawo”, t. 4, Lublin 1985, s. 31-32; J. Krukowski, Podstawowe zagadnienie prawa konkordatowego, „Studia Prawnicze” 1996, nr 1-4, s. 112-125, tenże, Konkordaty wspótczesne. Doktryna - teksty (1964-1994), Warszawa 1995, passim; A. Mączyński, Znaczenie konkordatu dla polskiego systemu prawnego, w: Rola i znaczenie konkordatu 1993, red. J. Dyduch, Kraków 1994, s. 69-95.

${ }_{76} \mathrm{~W}$ literaturze analizuje się przyczyny zawierania konkordatu, wskazując, że należało do nich po pierwsze dążenie do zlikwidowania konfliktów i przywrócenia zgody między kościołem a państwem. Układy zawierane na tym tle noszą nazwę „,konkordatów pokojowych" (concordata pacis) są one charakterystyczne, zwłaszcza dla początkowego okresu historii konkordatów. Przykładem takiego konkordatu pokojowego jest 
pierwszej wojnie światowej pewne państwa (m.in. Niemcy, Litwa) zawierały umowy zbliżone do konkordatu z niektórymi ośrodkami dyspozycyjnymi Kościołów protestanckich. Status prawny tego rodzaju umów wydaje się z punktu widzenia prawa międzynarodowego nader wątpliwy zważywszy, iż doktryna odmawia tego typu zwierzchnym organom kościołów prawa występowania jako podmiot w stosunkach międzynarodowych ${ }^{77}$.

konkordat wormacki (11-19 października 1119 r.) Konkordat napoleoński z (15 lipca 1801 r.), wreszcie tzw. traktaty laterańskie. Drugą przyczyną zawierania konkordatów jest dążenie stron do umocnienia panującej zgody, harmonii i przyjaźni (concordata amiciciae). Trzecią przyczyną zawierania konkordatów jest chęć uniknięcia lub pogorszenia stosunków między państwem a kościołem. Są to konkordaty obronne (concordata defensionism). Zob. T. Włodarczyk, Konkordaty, t. 1, Warszawa 1986, s. 36-37. (Przytoczony podział konkordatów zaczerpnął T. Włodarczyk z dzieła A. Ottaviani, Instyitutiones Iuris Publici Ecclesiastici, t. II, Romae 1948, s. 262.

77 Zważywszy, że Watykan nie licząc funkcjonariuszy kościoła nie posiada żadnej stałej ludności, a znaczną część funkcji administracyjnej na jego obszarze sprawują Włosi to według niektórych autorów nie może być mowy o uznaniu go za państwo. Zob. M. Mendelson, The Diminutive States in the United Nations, „International and Comparative Law Quarterly" 1972, nr 21, s. 609; por. M. N. Shaw, Prawo międzynarodowe, Warszawa 2000, s. 150. Duża część - jeśli nie większość przedstawicieli doktryny prawa międzynarodowego zalicza Città del Vaticano do grupy państw, przy czym niektórzy podkreślają suwerenny charakter tej jednostki. Por. D. Anzilotti, Kurs mieżdunarodnogo prawa, t. I, Moskwa 1971, s. 151; L. Oppenheim, M. Lauterpacht, International Law, London-New York 1958, s. 256; B. A. Graham, Vatican Diploma$c y$, Princeton-New Jersey 1959, s. 186. Inni uznając państwowy charakter tego podmiotu, podkreślają jednocześnie jego wyjątkowy, funkcjonalny charakter - np. P. Cipriotti uważa Państwo Watykańskie za ,"państwo-narzędzie”. Por. Stolica Święta - jej funkcja, osobowość i pozycja w prawie międzynarodowym, „Concillium” 1970, nr 6-10, s. 125; I de la Briére La conditton jurldigue de la Cité du Vatican, w: Recueil des Cours, t. 33 (1930-III), s. 123. W piśmiennictwie prawnomiędzynarodowym spotyka się także poglądy uznające Cittá del Vaticano za państwo wasalne Stolicy Apostolskiej - zob. np. J. L. Kunz, The Status of the Holy See in International Law, „The American Journal of'International Law" 1952, s. 308-314. W polskiej doktrynie prawa międzynarodowego L. Antonowicz traktuje Watykan jako państwo - zob. Pojęcie państwa w prawie międzynarodowym, Warszawa 1974, s. 89 i 157. Duża część doktryny neguje państwowy charakter Città del Vaticano, zaliczając ją jednocześnie do podmiotów prawa międzynarodowego. Ch. Rousseau i C. Berezowski zaliczają Państwo Watykańskie do niesuwerennych terytorialnych organizacji międzynarodowych zob. Ch. Bousseau, Etat de la Cité du Vatican, „,Revue General de Droit International Public" 1930, t. 3T, s. 145-153; C. Berezowski, op. cit., s. 70. Podobnie czynią autorzy cytowanego wyżej podręcznika C. Berezowski, W. Góralczyk, K. Libera, Prawo międzynarodowe publiczne, Warszawa 1967, s. 126. M. Sibert zalicza Państwo Watykańskie do „sztucznych” podmiotów prawa międzynarodowego (por. początek tego 


\section{Pluralistyczna koncepcja relacji między państwem a kościołem}

U źródeł tej koncepcji leży założenie, że postulat demokratyzacji będący podstawą społeczeństwa obywatelskiego nie może być zrealizowany, jeśli wierzący „nie będą się czuli u siebie”. W myśl tej koncepcji państwa europejskie, a szeroko rzecz ujmując państwa cywilizacji zachodniej, cechuje pluralistyczny charakter życia społecznego. W krajach tych zagadnienie ochrony wolności i praw obywateli, w tym także wolności sumienia i wyznania, wiąże się z podstawowymi cechami ustroju państwowego mieszczącego się w ogólnej formule demokratycznego państwa prawa. Zasadnicze znaczenie dla określenia stosunku państwa do kościołów i związków wyznaniowych ma kwestia postrzegania przez państwo swojej roli w ochronie praw i wolności obywatelskich oraz miejsce wartości religijnych w państwie. Wiąże się to z problemem równości zwolenników różnych kościołów i związków wyznaniowych wobec prawa. Przedstawiciele tej koncepcji podkreślają, że konkretne modele stosunków między państwem a kościołem powstawały na gruncie określonych doświadczeń historycznych. Zauważają także, że stosunek do religii oraz kościołów i związków wyznaniowych różnych sił politycznych w poszczególnych państwach jest w głęboki sposób zróżnicowany. Wynika to nie tylko z doświadczeń historycznych, ale z odmiennego rozumienia roli państwa $\mathrm{w}$ ochronie praw człowieka, $\mathrm{z}$ różnych form regulacji statusu kościołów i innych związków wyznaniowych oraz z faktu, że pojęciu świeckości państwa nadawana jest różna treść. Podkreśla się przy tym, że różnice te powstają na uniwersalnym gruncie, jakim są powszechnie uznane w Europie i uważane za wspólny dorobek ludzkości idee praw człowieka. Zwolennicy tej koncepcji stoją na stanowisku, iż rozwiązania prawne Rady Europy i Unii Europejskiej pozwalają na istnienie dość mocno różniących się systemów relacji między państwami a kościołami, a w ramach tych systemów rozmaitych rozwiązań szczegółowych. Punktem wyjścia tej systematyki jest analiza konstytucji i ustaw konstytucyjnych poprzez pryzmat ogólnych granic wytyczonych przez Unię i Radę Europy ${ }^{78}$. Kon-

rozdziału). Zdaniem R. Bierzanka, nie ma wątpliwości, że „Miasto Watykańskie” jest podmiotem prawa międzynarodowego - zob. B. Bierzanek, Współczesne stosunki międzynarodowe, Warszawa 1971, s. 103; por także J. Czaja, Prawnomiędzynarodowy status Watykanu, Warszawa 1983, s. 64 i n.

78 Koncepcję tę na gruncie polskim prezentuje M. Rynkowski, Status prawny kościołów i zwiąków wyznaniowych w Unii Europejskiej, Warszawa 2004; A Czochara, 
cepcja K. Orzeszyny wydaje się więc ściśle osadzona w materiale normatywnym. Nie uwzględnia ona, co wydaje się być jej słabością, polityki wyznaniowej państwa. Wywodzi się ona jednak także z pewnych koncepcji socjologiczno-kulturoznawczych poszukujących tożsamości cywilizacyjnej Europy i akcentującej jej korzenie judeochrześcijańskie ${ }^{79}$. Ta warstwa

Mechanizmy ochrony wolności sumienia i wyznania w państwach Europy Zachodniej, w: Dylematy wolności sumienia $i$ wyznania w państwach współczesnych, red. A. Czochara, B. Górowska, M. Nadolski, J. Osuchowski, Warszawa 1996, s. 61-63. Głęboką analizę rozwiązań prawnych dotyczących relacji między państwem a kościołem w konstytucjach państw członkowskich Unii Europejskiej przedstawił K. Orzeszyna, podejmując jednocześnie nieśmiałą próbę przeszczepienia na grunt Polski teoretycznych rozwiązań znanych w Europie Zachodniej. Zob. K. Orzeszyna, Podstawy relacji, s. 5 i n. Podjęta przez tego autora próba stworzenia własnej koncepcji klasyfikacji stosunków między państwem a kościołem wypada w warstwie teoretycznej dość blado mimo, iż autor ten dokonał głębokich studiów nie tylko rozwiązań konstytucyjnych istniejących w różnych państwach Europy, lecz także w odniesieniu do większości z tych państw zanalizował ustawy szczegółowe regulujące funkcjonowanie kościołów i związków wyznaniowych, orzecznictwo Trybunałów Konstytucyjnych, bądź Sądów Najwyższych oraz założenia doktrynalne przewijające się w myśli politycznej. Ten brak należytego zaakcentowania warstwy teoretycznej wydaje się do pewnego stopnia zrozumiały, jeśli zważyć, że K. Orzeszyna jest pracownikiem Katolickiego Uniwersytetu Lubelskiego, a jego koncepcja prezentowana w sposób dość zawiły i ascetyczny pozostaje w wyraźnej opozycji do cieszących się wielkim uznaniem koncepcji J. Krukowskiego (zob. tegoż, Polskie prawo wyznaniowe, Warszawa 2000; Kościół i państwo. Podstawy relacji prawnych, Lublin 2000), K. Warchałowskiego (zob. tegoż, Prawo do wolności sumienia $i$ wyznania w Europejskiej Konwencji Praw Człowieka i Podstawowych Wolności, Lublin 2004), A. Mezglewskiego, H. Misztala, P. Stanisza (zob. tychże, Prawo wyznaniowe, Warszawa 2006 oraz H. Misztala i P. Stanisza, Prawo wyznaniowe, Lublin 2003) wywodzących się z tegoż Uniwersytetu. Warto dodać, że koncepcja K. Orzeszyny jest także polemiczna w stosunku do rozwiązań proponowanych przez M. Pietrzaka, także jednego z wybitnych autorytetów w zakresie prawa wyznaniowego. Zob. M. Pietrzak, Prawo wyznaniowe, Warszawa 1993. Pewne założenia koncepcji, w nurcie której zaistniała praca K. Orzeszyny, sformułowali M. Safjan, C. Mik, M. Granat (zob. M. Safjan, Wolność religijna w konstytucjach państw europejskich, „Kultura i Prawo”, t. III: Religia i wolność religijna w Unii Europejskiej, Lublin 2003, s. 43-73; C. Mik, Czynniki religijny i etyczny w prawie i praktyce Unii Europejskiej, ibidem, s. 129-171; M. Granat, Granice wolności religijnej w społeczeństwie pluralistycznym, ibidem, s. 173-192). Wzorem dla koncepcji K. Orzeszyny było niewątpliwie opracowanie Państwo i Kościól w krajach Unii Europejskiej, red. G. Robbersa, Wrocław 2007.

${ }^{79}$ J. Kolasa, Europa - rodowód i tożsamość, w: Konstytucja dla Europy. Przyszły fundament Unii Europejskiej, red. S. Dudzik, Zakamycze 2005, s. 16; J. Życiński, Aksjologiczny fundament jedności europejskiej w perspektywie adhortacji, ,,Ecclesia in Europa", w: Kultura i Prawo. Religia i wolność religijna w państwach Europy Środ- 
na tle doskonale przeprowadzonych analiz tekstów normatywnych wydaje się być dość sztucznie doczepiona do zasadniczego trzonu wywodów. K. Orzeszyna stara się rozpoznawać relacje między państwem a kościołami, w aspekcie społeczeństwa obywatelskiego oraz społeczeństwa demokratycznego, stojąc na stanowisku, iż nie są to określenia synonimiczne ${ }^{80}$.

Obok rozważań znajdujących się w nurcie prac G. Robbersa, niewątpliwie inspiracją dla K. Orzeszyny była koncepcja R. Torfsa. R. Torfs przedstawi1 $^{81}$ trzy zasadnicze sposoby, w oparciu o które państwa i organizacje międzynarodowe podchodzą do problemu nowych ruchów religijnych. Pierwszy z nich, to model zaufania (confiance): demokratyczne państwo prawa i jego ustawodawca nie zauważają fenomenu nowych ruchów religijnych, a cały model cechuje wielka prostota i zaufanie, które wydaje się być ważniejsze niż ochrona własnych obywateli. Drugi model określany jest jako model czujności (vigilance). Opiera się on na koncepcji wolności wyznania, jednak przy świadomości, że wolność ta może zostać nadużyta. Równowaga między wolnością wyznania i ochroną społeczeństwa jest ważna, żadna z tych wartości nie przeważa. Trzeci

kowo-Wschodniej w perspektywie integracji europejskiej, red. J. Krukowski, Lublin 2004, s. 26-27; F. Gołembski, Tożsamość europejska (aspekty teoretyczne), w: Tożsamość europejska, red. F. Gołembski, Warszawa 2005, s. 32-33; S. Sulowski, Narodowa i europejska tożsamość z perspektywy niemieckiej, ibidem, s. 127. Żałować należy, że autor nie wykorzystał jednak prac zamieszczonych w zbiorze Tożsamość w czasach zmiany. Rozmowy w Castel Gandolfo, przygotował i przedmową opatrzył K. Michalski, Kraków 1995, w szczególności zaś zamieszczonego tam tekstu Spaemanna, Tożsamość religijna, s. 56-72.

${ }^{80} \mathrm{~W}$ analizach swoich opiera się na ustaleniach E. Shils, Co to jest społeczeństwo obywatelskie?, w: Europa i społeczeństwo obywatelskie. Rozmowy w Castel Gangolfo, red. K. Michalski, Kraków 1994, s. 10; J. Szacki, Wstęp. Powrót idei spoleczeństwa obywatelskiego, w: Ani ksiqżę, ani kupiec: obywatel. Idea spoleczeństwa obywatelskiego w myśli współczesnej, wybór teksów i wstęp J. Szacki, Kraków 1997, s. 10-11, 13; D. Pietrzyk-Reeves, Idea społeczeństwa obywatelskiego. Wspótczesna debata i jej źródta, Wrocław 2004, s. 311; D. I. Pietrzyk, Liberalne, demokratyczne czy obywatelskie? Spoleczeństwo obywatelskie a liberalna demokracja, „Państwo i Społeczeństwo" 2002, nr 2, s. 66; M. Walzer, Spór o spoteczeństwo obywatelskie, w: Ani ksiqżę, ani kupiec: obywatel. Idea społeczeństwa obywatelskiego w myśli współczesnej, wybór teksów i wstęp J. Szacki, Kraków 1997, s. 102-103.

${ }^{81} \mathrm{R}$. Torfs, Les nouveaus movements religieux et le droit dans 1'Union Européenne, rapport général, w: New religious movements and the law in the European Union, materiały z kolokwium, Lizbona 8-9 listopad 1997 r., wyd. Bruylant, Giuffr, Nomos Verlag, s. 39. 
model, sceptycyzm strukturalny (scepticisme structurel), jest odwrotnością modelu zaufania. Ochrona społeczeństwa jest najistotniejsza, może spowodować ograniczenie wolności wyznania, co jest akceptowaną konsekwencją tej polityki. Jest więc ona niekwestionowanym priorytetem. Jak podkreśla R. Torfs ${ }^{82}$, wszystkie przedstawione powyżej modele są zgodne z art. 9 Europejskiej Konwencji o Ochronie Praw Człowieka i Podstawowych Wolności. Pierwszy z nich odzwierciedla wyrażoną w ust. 1 tegoż artykułu wolność wyznania. Model sceptycyzmu strukturalnego opiera się na dopuszczonych w ust. 2 ograniczeniach, a model pośredni, czyli model czujności, stara się w sposób wyważony zapewnić realizację obu ustępów art. 9 Europejskiej Konwencji. Model zaufania, występuje - jak stwierdza R. Torfs - zarówno w wielu państwach członkowskich, jak i na gruncie prawa międzynarodowego ${ }^{83}$. Trzeba pamiętać, że koncepcja R. Torfsa odnosi się głównie do sekt i nowych ruchów religijnych, aczkolwiek wyróżnione przez niego modele pojawiają się także w kontekście istniejących już kościołów.

K. Orzeszyna, dokonując analizy relacji między państwami a kościołami, wyróżnia cztery modele: państwa wyznaniowe, państwa świeckie z radykalnym rozdziałem między państwem a kościołem, państwa świeckie z rozdziałem przyjaznym, z wyraźnym uznaniem pozycji prawnej niektórych kościołów z racji historycznych, wreszcie państwa świeckie z przyjaznym rozdziałem jednak bez wyraźnego uznania pozycji prawnej jednego z kościołów. Do państw wyznaniowych zalicza: Cypr, Danię Finlandię, Grecję, Maltę, Zjednoczone Królestwo Wielkiej Brytanii. Zdaniem $\mathrm{K}$. Orzeszyny państwa wyznaniowe to takie, które charakteryzują się obecnością kościoła narodowego lub religii dominującej. Kościół narodowy (taki charakter może mieć zarówno Kościół rzymskokatolicki, jak i jeden z Kościołów protestanckich, bądź prawosławnych) akcentuje zwykle to, że jego misja dotyczy całego narodu, całej populacji rozumianej jako wielka wspólnota. Kościół taki, ma zwykle ścisłe związki z kulturą naro-

82 R. Torfs, Les nouveaus, op. cit., s. 39 i n.

83 Początkowo, Rada Europy ustosunkowała się do problemu sekt liberalnie w zaleceniu nr 78(1992). W 1998 r. sprawozdawca rumuński A. Nastase opowiedział się za modelem czujności, idąc nawet w kierunku sceptycyzmu strukturalnego, co znalazło wyraz w nowym zaleceniu 1412 (1999) Zgromadzenia Rady Europy z 22 czerwca 1999 r., zatytułowanym „Nielegalna działalność sekt”, w którym zaproponowano m.in. utworzenie obserwatora europejskiego do spraw sekt, na wzór obserwatorów istniejących już w niektórych państwach. 
dową i z regionalnymi przejawami tej kultury. W państwach wyznaniowych istnieją mniej lub bardziej ścisłe związki między władzą państwową a takowym dominującym kościołem ${ }^{84}$.

Do państw świeckich z radykalnym rozdziałem stosunków między państwem a kościołem zalicza: Francję, Holandię (Królestwo Niderlandów), Irlandię. Państwa te według K. Orzeszyny funkcjonują w modelu liberalno-indywidualistycznym. Charakterystycznym dla niego jest to, że władze publiczne dystansują się od wszelkich ocen i odniesień związanych z religią. Prowadzi to do układania stosunków między państwem a kościołami i związkami wyznaniowymi, na zasadzie rozdziału radykalnego. W modelu tym państwo uważa religię za sprawę prywatną, starając się określić wolności kościołów. Najczęściej nie jest przy tym wrogie religiom i kościołom ${ }^{85}$.

Wśród państw świeckich z przyjaznym rozdziałem między państwem a kościołem i wyraźnym uznaniem pozycji prawnej jednego z kościołów z racji historycznych wskazuje: Austrię, Belgię, Bułgarię, Wielkie Księstwo Luksemburga, Litwę, Niemcy, Rumunię i Szwecję. Model ten wiąże K. Orzeszyna z koncepcją państwa liberalno-socjalnego, w którym państwo, pojmując swoją rolę jako służbę rozwojowi osobowości i godności człowieka, nie dystansuje się od akceptowanych powszechnie przez członków społeczności wartości i motywacji, lecz podporządkowuje się im, zgadzając się na przyporządkowane tym zasadom podstawowe wartości kulturowe. W modelu tym z jednej strony pojawia się podobne do liberalnego konstytucyjne ujęcie wolności obywatelskiej i podkreślenie niezależności prawa państwowego od kościelnego, z drugiej strony pojawiają się rozwiązania zasadzające się na pomocy państwa dla religii.

${ }^{84} \mathrm{Na}$ taką historyczną rolę Kościoła katolickiego w Polsce zwracają uwagę np. H. G. Wyczawski, Historia kościoła w Polsce, t. II: 1764-1945, cz. 2: 1918-1945, red. B. Kumor, Z. Obertyński, Poznań-Warszawa 1979, s. 12-22 oraz K. Śmigiel, ibidem, s. 148-171; N. Davies, Boże igrzysko. Historia Polski, Kraków 1991, s. 266-289; H. Wereszycki, Historia polityczna Polski 1864-1918, Wrocław-Warszawa-Kraków-Gdańsk-Lódź 1990, s. 66 i n.; A. Friszke, Polska. Losy państwa i narodu 1939-1989, Warszawa 2003, s. 196-201; F. Koneczny, Święci w dziejach narodu polskiego, Kraków 1985, passim; K. Kłoczowski, Kościół katolicki w świecie i w Polsce, „Szkice Historyczne”, Katowice 1986, s. 71-124; tenże, Dzieje chrześcijaństwa polskiego, wyd. uzup., Warszawa 2007, passim.

A. Czochara, Stosunki państwo kościót. Belgia, Francja, Hiszpania, Włochy, Warszawa 1994, s. 33-34 i 71; K. Orzeszyna, Podstawy relacji między państwem a kościołami, s. 99. 
K. Orzeszyna konstatuje, że model rozdziału przyjaznego cechują sprzeczności między obowiązującymi zasadami polityki państwa prawa, częstokroć wynikającymi z ustawodawstwa europejskiego, a regulacjami mającymi prowieniencję historyczną, których nie pozbawiono mocy prawnej, mimo że są one wytworem nie istniejących już realiów społeczno-politycznych ${ }^{86}$. Zaliczając generalnie do poszczególnych modeli państwa czyni wyjątek w odniesieniu do francuskich departamentów Dolnego i Górnego Renu oraz Mozeli, które chce traktować odrębnie niż pozostałe tereny Francji, słusznie zauważając, że te tereny do roku $1871 \mathrm{r}$. miały ten sam model prawa wyznaniowego co inne prowincje francuskie, ale po aneksji ich przez Niemcy dekrety cesarskie zmieniły niektóre przepisy dotyczące spraw wyznaniowych. Ponieważ obszar ten wrócił do Francji po 1918 r. to nie obowiązywała na nim francuska ustawa z 9 grudnia 1905 r. dotycząca rozdziału kościoła od państwa. System ten został utrzymany po powrocie wspomnianych obszarów do Francji ${ }^{87}$.

Do państw świeckich z przyjaznym rozdziałem stosunków między państwem a kościołem bez wyraźnego uznania pozycji prawnej jednego z kościołów zalicza K. Orzeszyna: Czechy, Estonię, Hiszpanię, Łotwę, Polskę, Portugalię, Słowację, Słowenię, Węgry, Włochy. Typizacja ta może budzić pewne wątpliwości wynikające $\mathrm{z}$ faktu, iż autor skupił się na analizie normatywnej, pomijając całkowicie kwestie politologiczne.

${ }^{86}$ K. Orzeszyna, Podstawy relacji między państwem a kościołami, s. 99; A. Czochara, Stosunki państwo kościót, s. 72.

87 Departamenty Dolny i Górny Ren oraz Mozela obejmują teren Alzacji i Lotaryngii. Na tym obszarze ustawodawstwo wyznaniowe traktowane jest jako prawo lokalne. W przypadku wątpliwości interpretacyjnych rozstrzygające jest odwołanie się do Konstytucji V Republiki. Na tym obszarze obowiązuje podział wyznań na uznane i nieuznane. Do uznanych należą: katolickie, luterańskie, reformowane (kalwińskie) i żydowskie. Do nieuznanych należą: islam, prawosławie, pozostałe kościoły protestanckie oraz nowe ruchy religijne. Praktykowanie kultów nieuznanych teoretycznie uzasadnione jest od otrzymania pozwolenia, faktycznie wierni organizują się w stowarzyszenia, aby uzyskać dla swojego wyznania osobowość prawną i wpis do rejestru. We wspomnianych departamentach istnieją dwie diecezje katolickie: Metz, obejmująca departament Mozela oraz diecezja strasburska obejmująca departamenty Dolnego i Górnego Renu. Diecezje te przed 1871 r. należały do arcybiskupstwa Besançon obecnie zaś bezpośrednio podlegają Stolicy Apostolskiej. W 1988 r. Strasburg zosta1 podniesiony do rangi arcybiskupstwa. Zob. H. Łakomy, Państwo a kościót we Francji. Historia a współczesność, Kraków 1999, s. 23 i n.; G. Desos, Le régime particulier des cultes dans les départements du Bas-Rhin, du Haut-Rhin et de la Moselle, „Administration" 1993, nr 161, s. 55. 
Takie nieuwzględnienie realiów politycznych spowodowało, że do ostatniego z modeli zaliczono zarówno Polskę, jak i Włochy ${ }^{88}$, gdzie rola Kościoła katolickiego z przyczyn historycznych i z tej racji, że wyznawcami tej religii jest większość obywateli jest znacznie większa niż to wynikałoby z aktów normatywnych. Także w Portugalii Kościół katolicki cieszy się specjalnym statusem potwierdzonym ustawą o wolności religijnej z 22 czerwca $2001 \mathrm{r} .{ }^{89} \mathrm{~W}$ literaturze portugalskiej podkreśla się, że w sto-

88 System stosunków między państwem a kościołami i związkami wyznaniowymi we Włoszech omówiono wyżej.

${ }^{89}$ Ustawa z 22 czerwca 2001 r. o wolności religijnej uzupełniona przez dekret ustawę 134/2003 z 28 czerwca, o rejestracji wyznaniowych osób prawnych; przez dekret - ustawę 194/2003 z 23 sierpnia, odnośnie opłat; przez dekret - ustawę 308/2003 z 10 grudnia, o Komisji Wolności Religijnej, w art. 58 zawiera zastrzeżenie gwarantujące, że konkordat pomiędzy Portugalią a Stolicą Apostolską pozostaje w mocy, co jak stwierdza się w literaturze wzmacnia roszczenia Kościoła katolickiego o utrzymanie specjalnego statusu. Konkordat przyznaje Kościołowi katolickiemu szereg przywilejów, upoważniając ten Kościół do przedstawienia swojego zdania w sprawie przeznaczenia określonych terenów na cele religijne, daje także uprawnienia podatkowe. Zob. V. Canas, Państwo i kościół Portugalii, w: Państwo i kościół w krajach Unii Europejskiej, s. 303-322. W literaturze podkreśla się, że wpływ Kościoła katolickiego na kulturę i edukację jest znaczący, a wpływ innych wyznań nieznaczny. Wynika to z faktu, że pod wieloma względami dzieje Portugalii są nierozerwalnie związane z Kościołem katolickim. Wiele budynków należących do Kościoła to narodowe zabytki. Kościół katolicki prowadzi wyznaniowe szkoły teologiczne oraz prestiżowy Uniwersytet, jest też właścicielem ogólnokrajowej stacji telewizyjnej Rádio Renascença. W myśl konkordatu, duchowni Kościoła katolickiego mają prawo udzielania ślubów zgodnie z prawem kanonicznym. W 2001 r. uprawnienia takie uzyskały inne wyznania. Portugalskie prawo wyznaniowe definiuje kościoły i związki wyznaniowe jako „zorganizowane wspólnoty społeczne”, które gwarantują długotrwały byt, w ramach którego wyznawcy mogą realizować swoje cele wyznaniowe określone przez religię (art. 20 ustawy o wolności religijnej). W Portugalii wyróżnia się trzy kategorie kościołów i związków wyznaniowych: osiadłe lub zakorzenione kościoły i związki wyznaniowe, kościoły i związki wyznaniowe wpisane do rejestru zbiorowych podmiotów religijnych, a przez to posiadające podmiotowość prawną, kościoły i związki wyznaniowe nieposiadające podmiotowości prawnej, ponieważ nie zostały wpisane do rejestru zbiorowych podmiotów religijnych. Status Kościoła katolickiego jako osoby prawnej został uznany z mocy konkordatu z 1940 r., zmienionego przez konkordat z 2004 r. Inne kościoły i związki wyznaniowe nabywają status zbiorowych podmiotów wyznaniowych, a tym samym podmiotowość prawną poprzez wpis do rejestru. Rejestracja ta nie ma jednak charakteru obowiązkowego. Status osiadłego, zakorzenionego kościoła lub związku wyznaniowego posiadają kościoły i związki wyznaniowe istniejące w Portugalii od co najmniej 30 lat, posiadający znaczącą liczbę członków lub funkcjonujące za granicą od ponad 60 lat. Status ten przyznawany jest przez Rząd po 
sunkach między państwem a Kościołem katolickim zagwarantowano temu Kościołowi specjalny status opierający się na instrumentach i przepisach innego poziomu niż Konstytucja. Konkluduje się przy tym, że system stosunków między państwem a Kościołem w Portugalii da się opisać jako łagodny rozdzia9 ${ }^{90}$. W modelu przyjaznego rozdziału bez wyraźnego uznania pozycji prawnej jednego z kościołów bądź wyznań podstawowym problemem jest, jak stwierdza K. Orzeszyna, zagwarantowanie praw kościołom i wyznaniom mniejszościowym. Ochronie praw mniejszości wyznaniowych służyć ma zasada wolności i równości religijnej rozumiana jako idea „równej wolności” ${ }^{\text {"1 }}$. W modelu tym stosunki między państwem a kościołami i związkami wyznaniowymi opierają się z jednej strony na zasadzie niezależności i autonomii kościołów i związków wyznaniowych w wykonywaniu funkcji religijnych, z drugiej zaś na idei współdziałania państwa z kościołami i związkami wyznaniowymi. Aktywność państwa nie wynika z bezpośrednio pozytywnej oceny wartości afirmowanych przez kościoły i związki wyznaniowe, lecz z uznania nadrzędnego nad strukturami państwowymi znaczenia praw człowieka oraz służebnej roli państwa w rozwijaniu osobowości i godności człowieka ${ }^{92}$.

Koncepcja prezentowana przez K. Orzeszynę, aczkolwiek trudno ją uznać za w pełni oryginalna, gdyż autor mocno wzorował się na przywoływanych przez siebie tekstach obcojęzycznych, zwłaszcza pracy pod red. Gerharda Robbersa, co absolutnie nie umniejsza znaczenia prezentowanej przez niego klasyfikacji, wydaje się zbytnio hołdować analizie normatywnej. Nie mniej w istocie rzeczy właśnie rozwiązania normatywne

zasięgnięciu opinii Komisji Wolności Religijnej utworzonej w oparciu o ustawę o wolności religijnej. Status kościoła osiadłego ma znaczenie, gdyż łączy się z nim prawo do udzielania ważnych ślubów, zgodnie z prawem danego wyznania, prawo do zawierania porozumień z rządem odnoście kwestii mających znaczenie dla obu stron, prawo do uczestnictwa w Komisji Wolności Religijnej. Możliwość otrzymywania $0,5 \%$ podatku dochodowego od swoich wyznawców, wreszcie do zwrotu VAT w pewnych przypadkach. Zapobiega to sytuacji, w której nowe ruchy religijne, co do których celów i intencji mogą istnieć wątpliwości będą miały dostęp do przywilejów i praw. $Z$ drugiej strony system ten pozostawia decyzję czy dany związek jest osiadły, czy nie starszym i godnym zaufania kościołom oraz związkom wyznaniowym, gdyż rejestracja ta zależy od opinii Komisji Wolności Religijnej.

90 V. Canas, Państwo i kościót Portugalii, w: Państwo i kościót w krajach Unii Europejskiej, s. 322.

K. Orzeszyna, Podstawy relacji między państwem a kościołami, s. 171; A. Czochara, Stosunki państwo kościót, s. 73-74.

92 A. Czochara, Stosunki państwo kościót, s. 34-35. 
pozwalają na określenie rzeczywistej sytuacji prawnej kościołów i związków wyznaniowych. Pewną słabością tej koncepcji jest fakt, że w podsumowaniu autor mimo wszystko wrócił do wydawałoby się trwale zarzuconej przez siebie koncepcji J. Krukowskiego, wyróżniającego tylko dwa przeciwstawne modele państwa wyznaniowego i świeckiego.

Prezentowane systemy stosunków i modele w gruncie rzeczy prowadzą do jednoznacznego wniosku, że w obecnie globalizującym się świecie nie ma miejsca na nietolerancję, aczkolwiek ciagle odradzają się prądy integrystyczne i fundamentalistyczne. Koncepcja społeczeństwa obywatelskiego, państwa prawa, normy unijne i Rady Europy jednoznacznie wskazuja, iż państwa muszą ułożyć w płaszczyźnie prawa wyznaniowego tak stosunki, aby mniejszości wyznaniowe nie były dyskryminowane i nie czuły się dyskryminowane. Stworzenie przyjaznych dla wyznawców wszelkich kościołów i związków wyznaniowych norm to dopiero początek drogi. Dalszym etapem na niej jest taka działalność polityczna, taka wykładnia treści tych norm, aby ludność w sferze stosunków faktycznych nie mogła odnotować dyskryminacji ${ }^{93}$. Jest to zadanie trudne, zważywszy iż przedstawiciele kościołów i wyznań skupiających większość ludności lub takie, które zapisały piękną kartę historii określonych państw lub narodów mogą odczuwać jako dyskryminację to, że nie przyznaje się im lepszych uprawnień od tych, którymi cieszą się wyznawcy religii nowych na danym obszarze lub mało liczebnych, lub z tych tylko racji, że określony związek wyznaniowy posiada reprezentację, której przyznaje się zdolność traktatową ${ }^{94}$. Takie rozumienie równości i równouprawnie-

93 A. Habrat, Prawo i moralność jako wyznaczniki tolerancji, w: Europejskiej modele tolerancji, red. A. L. Zachariasz, S. Symotiuk, przy współpracy I. Różyckiej, Rzeszów 2001, s. 177; A. L. Zachariasz, Tolerancja a nie tolerancja: granice zasadności i konsekwencje praktyczne, ibidem, s. 37-52; A. Bobko, Tolerancja a wolność, ibidem, s.53-58; W. Zięba, Zagadnienie tolerancji w perspektywie sporu relatywizmu z absolutyzmem, ibidem, s. 93-102; H. Szabała, Tolerancja a transformacja społecz$n a$, ibidem, s. 103-116. Dyskusja wokół pojęcia tolerancji w filozofii nowożytnej została przedstawiona w książce L. Legutko, Tolerancja, Kraków 1999, passim.

94 Takie stanowisko zajmuje J. Krukowski stwierdzając: ,zasada równouprawnienia kościołów i związków wyznaniowych wobec państwa stanowi podstawowy element demokratycznego państwa świeckiego [...]. Biorąc pod uwagę kryterium zasady równouprawnienia kościołów należy odrzucić postulaty zwolenników prymitywnego egalitaryzmu, utożsamiającego równouprawnienie z identycznością. Taki prymitywizm w pojmowaniu zasady równouprawnienia ma miejsce wtedy, gdy słabsi odwołują się do zasady równouprawnienia, aby ściągnąć silniejszych do swego poziomu. Prymitywne pojmowanie egalitaryzmu zakłada identyczne traktowanie wszystkich 
nia kościołów i związków wyznaniowych, którym w istocie odmawia się tego równouprawnienia uciekając się do niezwykle konfrontacyjnego języka, zarzucając adwersarzom „prymitywizm” zdaje się dowodzić, że idee równouprawnienia wyznań i tolerancji religijnej nie zostały zinternalizowane w niektórych środowiskach naukowych, gdyż przedstawiciele ich „równouprawnienie” i ,równość” chcą tłumaczyć i wykładać jako możliwość stosowania przywilejów dla religii, którą wyznają.

\section{Summary}

The systems and models of relationship which are presented lead to a unanimous conclusion that the present globalizing world leaves no room for intolerance; however, the integrist and fundamentalist tendencies keep reviving. The concept of civic society, the state of law, the standards of the EU and Council of Europe provide a clear indication for states to develop such relations with respect to the law on religious denomination that will prevent religious minorities from being, or feeling, discriminated against. The establishment of standards which are friendly for all churches and religious associations is only the beginning, though. The next stage involves political activity and the interpretation of the regulations allowing for the elimination of discrimination from the realm of actual relations.

podmiotów należących do danego zbioru i to pod każdym względem, mimo istniejących między nimi różnic. Takie utożsamianie równości z identycznością różnych podmiotów prawa jest sprzeczne z wymogami sprawiedliwości rozdzielczej. Prymitywny egalitaryzm w pojmowaniu równouprawnienia w odniesieniu do kościołów oznaczał zredukowanie uprawnień wszystkich kościołów i innych związków wyznaniowych do uprawnień jednego z nich np. do związku wyznaniowego, który ma najmniejszą liczbę wyznawców w danym kraju”. Dalej J. Krukowski stwierdza: „Dlatego też tam, gdzie między kościołami zachodzą znaczące różnice, należy każdy z nich potraktować w sposób odmienny i zawsze odpowiednio do tego zróżnicowania. Nie jest więc sprzeczne z zasadą równouprawnienia kościołów zróżnicowane formy regulacji ich sytuacji prawnej ze względu na to, iż tylko Kościół katolicki reprezentowany przez Stolicę Apostolską posiada podmiotowość publiczno-prawną w stosunkach międzynarodowych, a tym samym zdolność do zawarcia umowy międzynarodowej. Zaś wszystkie inne kościoły i związki wyznaniowe takiego atrybutu nie posiadają”. J. Krukowski, Polskie prawo wyznaniowe, s. 59-60. 